Portland State University

PDXScholar

\title{
The stratigraphy of the Scappoose formation, the Astoria formation, and the Columbia River basalt group in northwestern Columbia County, Oregon
}

Nancy Tompkins Ketrenos

Portland State University

Follow this and additional works at: https://pdxscholar.library.pdx.edu/open_access_etds

Part of the Geology Commons, and the Stratigraphy Commons Let us know how access to this document benefits you.

\section{Recommended Citation}

Ketrenos, Nancy Tompkins, "The stratigraphy of the Scappoose formation, the Astoria formation, and the Columbia River basalt group in northwestern Columbia County, Oregon" (1986). Dissertations and Theses. Paper 3632.

https://doi.org/10.15760/etd.5500

This Thesis is brought to you for free and open access. It has been accepted for inclusion in Dissertations and Theses by an authorized administrator of PDXScholar. Please contact us if we can make this document more accessible: pdxscholar@pdx.edu. 
AN ABSTRACT OF THE THESIS OF Nancy Tompkins Ketrenos for the Master of Science in Geology presented February 27, 1986.

Title: The stratigraphy of the scappoose Formation, the Astoria Formation, and the Columbia River Basalt Group in Northwestern columbia County, oregon.

APPROVED BY MEMBERS OF THE THESIS COMMITTEE:

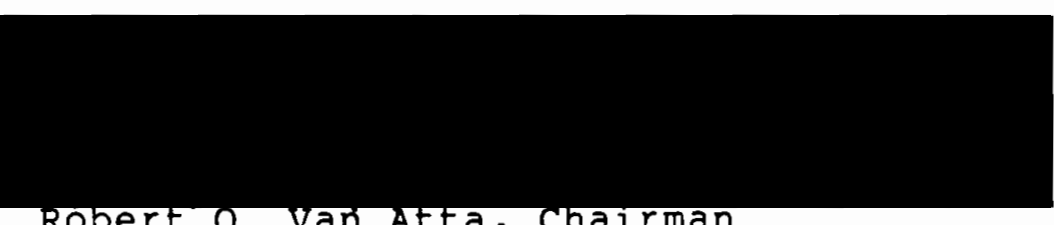

Robert o. van Atta, chairman
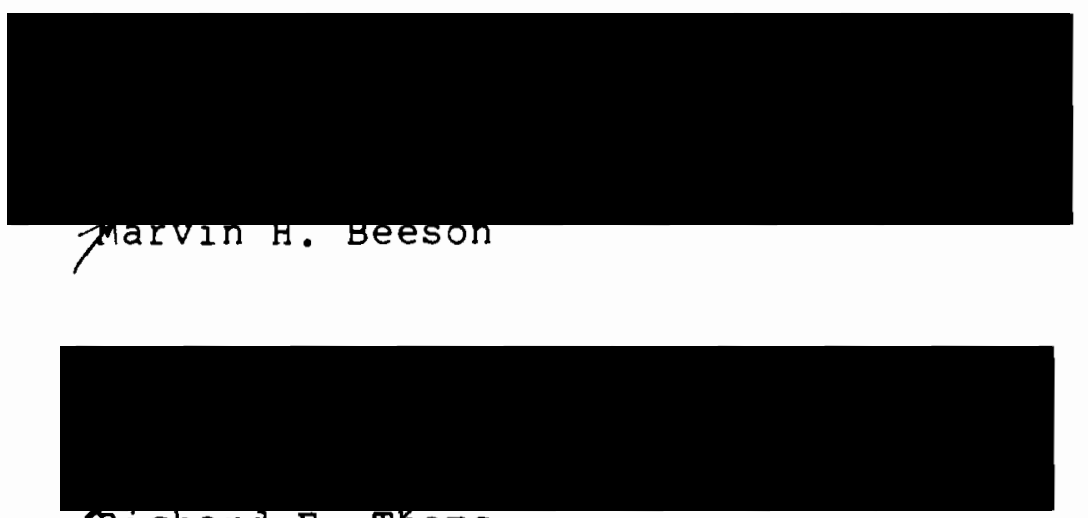

RichardE. Ihoms

The study area is located in northwestern columbia County, and covers an area of approximately 70 square kilometers. The purpose of the study was to investigate the possible correlation of the Scappoose and Astoria 
Formations and determine their stratigraphic relationship to the Columbia River Basalt Group through mapping, geochemistry and petrography.

The sedimentary formations exposed in northwestern Columbia County include the Keasey, Pittsburg Bluff, and the scappoose formations. Gray fossiliferous and tuffaceous mudstone of the Reasey Formation is overlain by marine arkosic sandstone of the Pittsburg Bluff Formation. The lower, fine grained, marine sandstone is overlain by an upper sandy siltstone which is capped by trough crosslaminated, lignitic, pebbly, silty sandstone and siltstone. These are overlain by a framework supported conglomerate composed of basalt and mudstone clasts. The clasts are derived from the middle Miocene Columbia River Basalt Group.

On Clatskanie Mountain, this conglomerate forms the base of the scappoose Formation which otherwise consists of micaceous lithic arkosic to quartz-rich arkosic cross-bedded and cross-laminated sandstone, siltstone, and mudstone. The scappoose formation is overlain by pillows and breccias of the Frenchman Springs Member of the Wanapum Basalt. The Scappoose formation sedimentary rocks exposed on clatskanie Mountain are correlative with the Scappoose Formation described to the southeast.

Poorly to moderately sorted grains, small scale primary structures, conglomerate, and the abundance of 
lignitic wood indicate deposition of the scappoose Formation sediments in a fluvial environment.

On Clatskanie Mountain, the Scappoose Formation underlies and is intercalated with the wanapum Basalt. A distinctive sandstone bed underlies a sand Hollow (informal) flow. The bed is quartz-rich coarse grained arkosic sandstone which is stratigraphically, petrographically, and geochemically correlative with similar beds of the Astoria Formation in clatsop County. Other sandstone and siltstone beds of the scappoose formation, which appear to have been deposited on the margins of basalt flows are stratigraphically, petrographically, and geochemically equivalent to beds of the Astoria Formation to the west on Nicolai Mountain and near Big Noise Creek. 


\section{THE STRATIGRAPHY OF THE SCAPPOOSE FORMATION, THE ASTORIA FORMATION, AND THE COLUMBIA RIVER BASALT GROUP IN NORTHWESTERN COLUMBIA COUNTY, OREGON}

$$
\text { by }
$$

NANCY TOMPKINS KETRENOS

A Thesis submitted in partial fulfillment of the requirements for the degree of

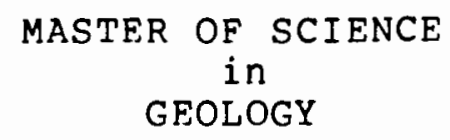

Portland State University 
TO THE OFFICE OF GRADUATE STUDIES AND RESEARCH:

The members of the Committee approve the thesis of Nancy Tompkins Ketrenos presented February 27, 1986.
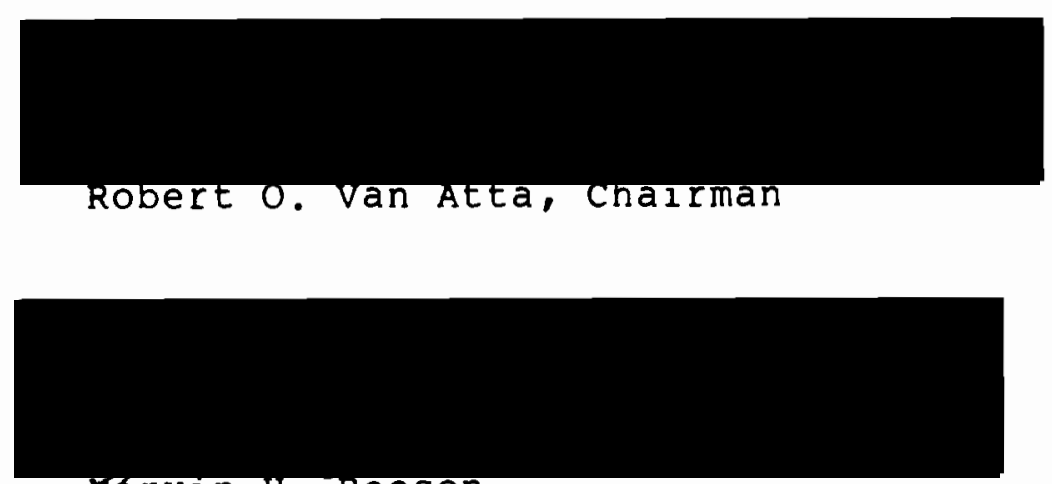

gárvin H. Beeson

Kichard E. Thoms

APPROVED :

Paul E. Hamnond, Head, Department of Geology 


\section{ACKNOWLEDGMENTS}

There are several people who deserve recognition and thanks for helping and encouraging me with this study. Dr. R. O. Van Atta, my thesis advisor, deserves special thanks for initiating this study, helping, and encouraging me with the field work and writing of this thesis. I also want to thank the other members of my committee. Dr. M. H. Beeson was generous with his time, and discussions with him were very helpful.

I wish to thank the Portland state Geology Department faculty for financial assistance from the Rockie Fund.

Nina Triffleman, Rebecca Heisler, and Karen Wilson provided much encouragement and field assistance.

A special thanks to Dr. Ann weikel who provided constant encouragement.

My parents, Rodney and Beryl Tompkins, have my gratitude for their support and encouragement. Without their help, this study would not have been completed. My father made countless trips into the field and helped in numerous ways with this study. 
I want to express my gratitude to my children for their encouragement. My son, Mark Ketrenos, deserves special recognition for his able assistance in the field and in other ways. 
ACKNOWLEDGMENTS ........................... iii

LIST OF TABLES........................... vii

LIST OF FIGURES ........................ viii

LIST OF PLATES............................

INTRODUCTION .............................. 1

PURPOSE OF STUDY........................ 1

LOCATION AND ACCESS..................... 3

METHODS OF INVESTIGATION.................. 4

PREVIOUS WORK......................... 5

Scappoose Formation.................. 6

Columbia River Basalt Group............. 11

REGIONAL GEOLOGY ........................... 16

REGIONAL STRUCTURE................... 17

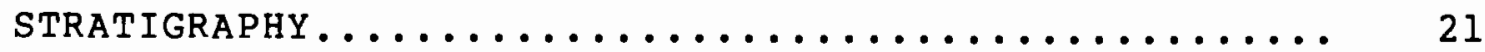

KEASEY FORMATION......................... 21

PITTSBURG BLUFF FORMATION................. 21

SCAPPOOSE FORMATION........................ 24

COLUMBIA RIVER BASALT GROUP................ 33

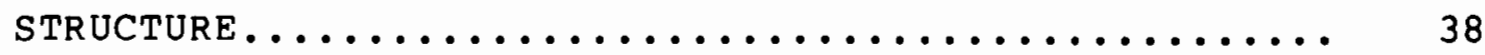

GEOCHEMISTRY ................................ 39

PETROGRAPHY............................... 53

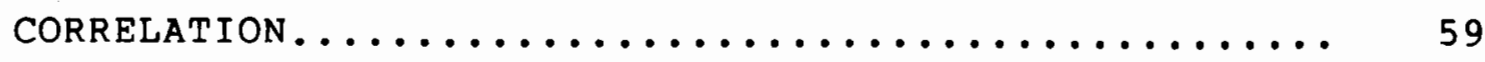


PAGE

SUMMARY ............................. 64

DISCUSSION AND CONCLUSION.................... 65

DEPOSITIONAL ENVIRONMENT................. 65

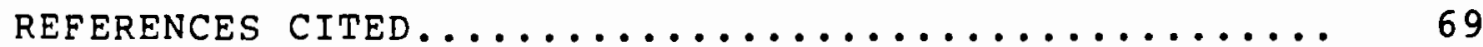

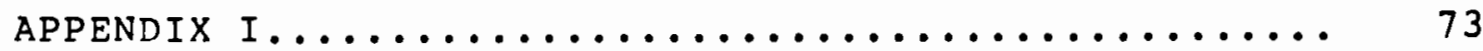

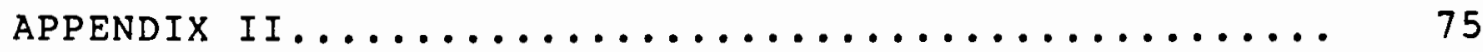

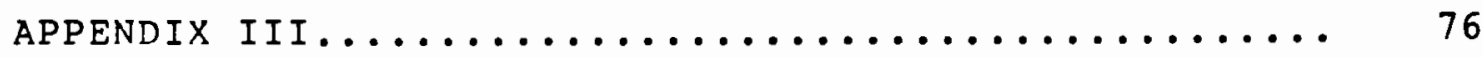




\section{LIST OF TABLES}

TABLE

PAGE

I Major Oxide Geochemical Analysis of

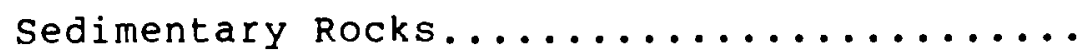

I Major Minor and Trace Element Geochemistry

of sedimentary Rocks.................

II Major Oxide and Geochemical Analysis

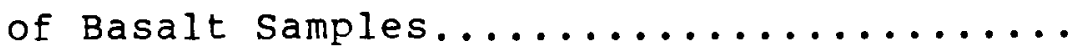




\section{LIST OF FIGURES}

F IGURE

PAGE

1. Index map of study area................

2. Correlation chart of measured sections

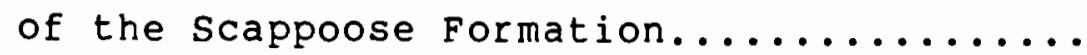

3. Correlation chart of Upper Nehalem River basin and northwest columbia county.......

4. Columbia River Basalt Group stratigraphy...

5. Minor and trace element concentrations

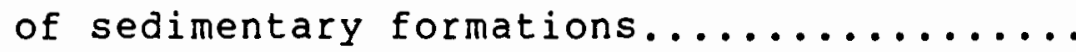

6. Regional Bouguer gravity map of northwest oregon and southwest washington...........

7. Cross-bedded sandstone and siltstone of the Pittsburg Bluff Formation..........

8. Measured section along Longview Fibre

Mainline on clatskanie Mountain..........

9. Mudstone and basaltic clast conglomerate at base of Scappoose Formation...........

10. Basaltic conglomerate at base of

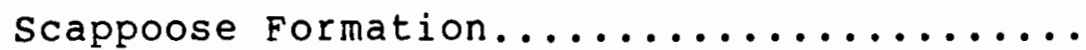

11. Cross-bedded arkosic sandstone overlying basaltic conglomerate................

12. Measured section along oregon Hwy $47 \ldots \ldots \ldots$ 
13. Frenchman springs Member intercalated

with scappoose Formation sandstone........

14. Sandstone of the scappoose Formation forms plume in Frenchman springs Member.........

15. Concentrations of Na20, K20, A1203, and

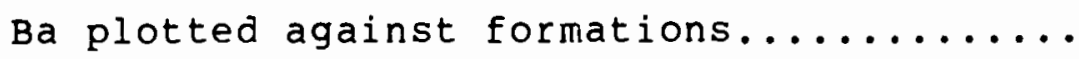

16. Concentrations of Sc, Ti02, Sr, and La

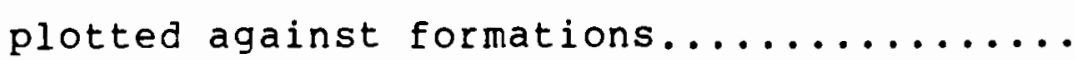

17. Concentrations of $\mathrm{Ce}, \mathrm{Sm}, \mathrm{Eu}$, and $\mathrm{Yb}$

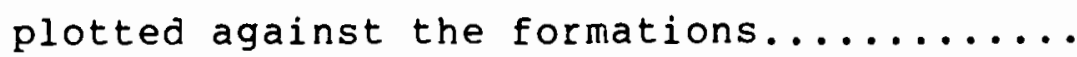

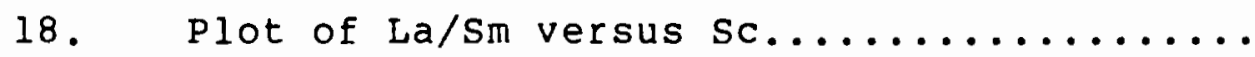

19. P205 versus Ti02 diagram of basalt

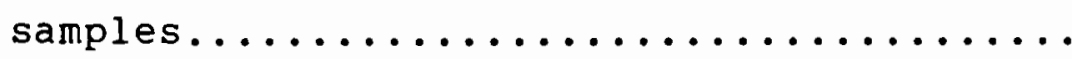

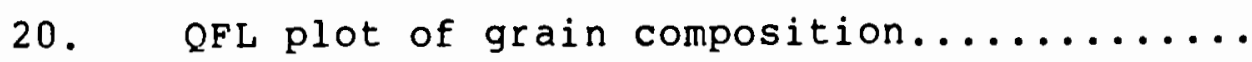

21. QmFLt plot of Pittsburg Bluff, scappoose

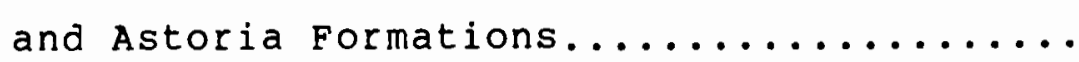

22. Fluvial sandstone interbed on

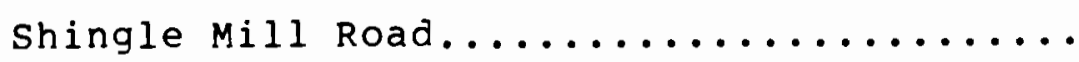

23. Sketch diagram of channel-fill geometry

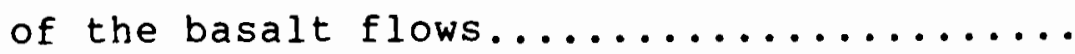




\section{LIST OF PLATES}

\section{PLATE}

1. Geologic map of northwest Columbia

County, oregon.................... pocket 
INTRODUCTION

PURPOSE OF STUDY

The relationship between the mid-Miocene marine Astoria and the terrestrial scappoose Formations in northwestern Columbia County, Oregon (Figure 1) is the subject of this study. The scappoose Formation has been described to the southeast of the study area, and the Astoria Formation has been mapped to the west in clatsop county. The nature of the interrelationship of the Astoria and Scappoose Formations is examined, and the stratigraphic relationship of both the scappoose formation and the Astoria Formation to the Columbia River Basalt Group is also examined. A geologic map of northwestern columbia county, oregon is revised, the sedimentary and volcanic rocks are described petrographically and geochemically. Through mapping, petrography and geochemistry, this study correlates the scappoose Formation in northwestern columbia County with the Astoria Formation to the west of the study area.

These formations are exposed in the coast Range mountains of northwestern oregon which are underlain by up to 6,995 meters of Tertiary sedimentary rocks and basaltic lava flows ranging in age from Eocene to pliocene (Armentrout, 1983). 


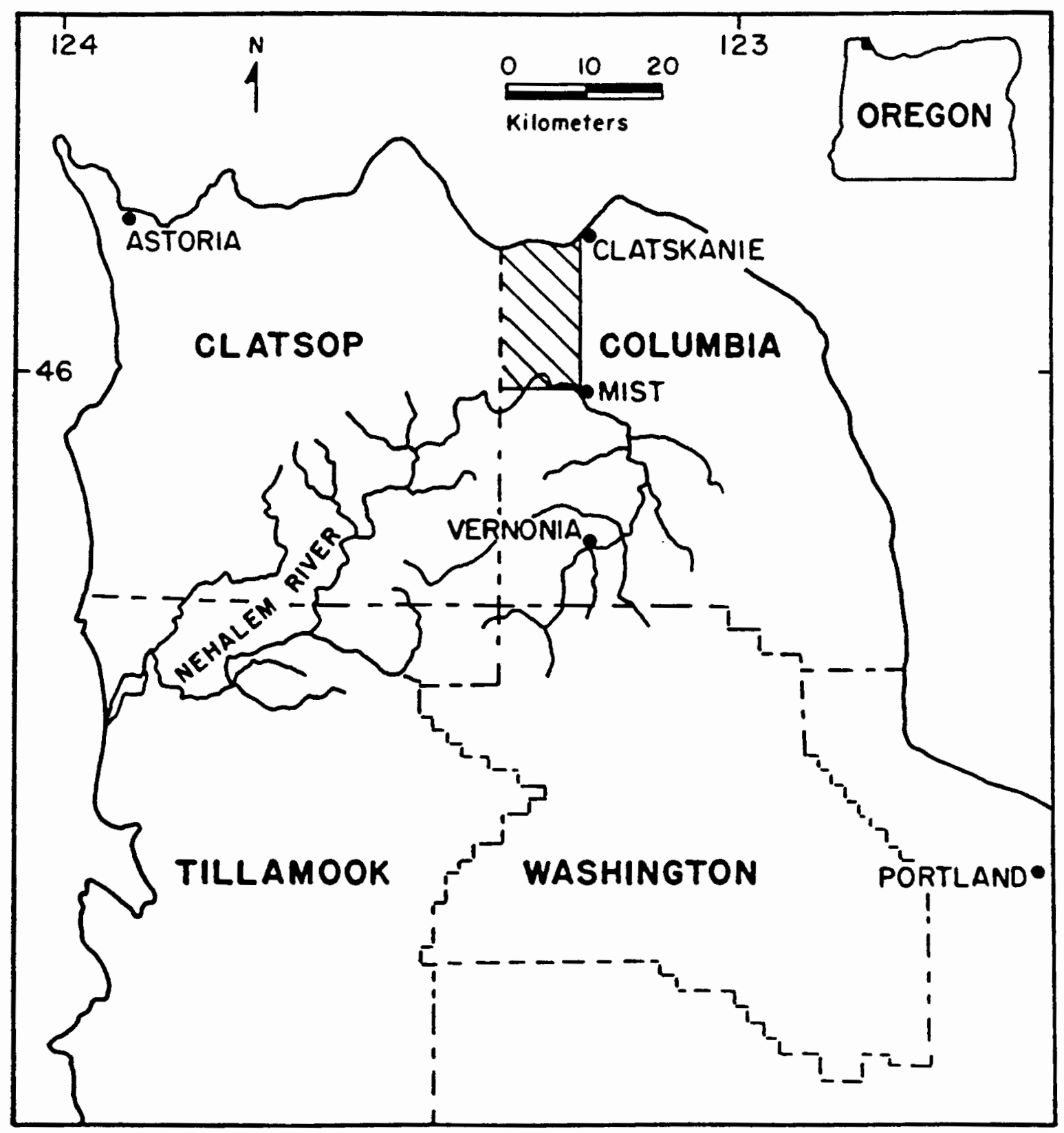

Figure 1. Index map showing study area and its Iocation in northwestern oregon. 


\section{LOCATION AND ACCESS}

The mapped study area includes parts of Townships 6 and 7 North, Range 5 West, willamette Meridian, the southeast $1 / 4$ of the Cathlamet Quadrangle, and is roughly bounded by U.S. Highway 30 on the north, and oregon Highway 202 on the south. The eastern and western boundaries are defined by oregon Highway 47 and the clatsop-columbia County line respectively.

Deep ravines and high ridges make up the terrain with a relief of approximately 615 meters $(2,000$ feet $)$ and a maximum elevation of approximately 640 meters $(2,080$ feet) on Clatskanie Mountain.

The major streams include Ford, Adams, Beaver, Mccoon, and Fishhawk creeks in the Nehalem River drainage basin. The streams generally have a northeast-southwest trend. Fall, Graham, Tellertson, Olson, and Ross creeks flow from southwest to the northeast draining into the columbia River. These streams probably follow regional northeastsouthwest structural trends.

Northwestern Columbia county is located approximately $65 \mathrm{kilometers}$ from Portland by either oregon Highway 47 or U.S. Highway 30. Access to the interior of the study area is good via paved and gravelled county roads and private logging roads. 
Because of the dense vegetation, bedrock exposures are confined to roadcuts and the banks and beds of streams.

\section{METHODS OF INVESTIGATION}

Field work was conducted during the summer and fall of 1984 and 1985. Geologic mapping was done at a scale of 1:24,000. Attitudes of bedding planes were measured with a Brunton compass, stratigraphic sections were measured with a tape, and thicknesses of beds were calculated using the attitude of the bed.

Laboratory samples were selected from the northwestern Columbia county and areas in clatsop county that appeared to be stratigraphically equivalent to the study area.

Seventeen samples were washed through a 270 mesh sieve to remove the silt. The remaining sand grains were impregnated under high pressure and stained for both potassium feldspar and plagioclase by quality Thin sections of Tucson, Arizona.

Basalt and sedimentary samples were sent to Dr. Peter Hooper at Washington State University for x-ray fluorescence analysis of major oxides. sedimentary samples were sent to Dr. Hooper, who forwarded them to a laboratory in England, for Inductively Coupled Plasma Emission spectrometry (ICP) analysis of minor and trace elements.

Paleomagnetism of basalt flows was determined with the use of a fluxgate magnetometer during the course of field 
work. This was particularly useful in discriminating between the flows of the Grande Ronde Basalt. Both the low Mgo (informal) and the high Mgo (informal) Grande Ronde geochemical type basalt contain flows of reversed and normal polarity. Flows of the Frenchman springs Member of the wanapum Basalt all show normal polarity (Beeson and others, 19851 .

The low Mgo and high Mgo flows of the Grande Ronde Basalt, and the Ginkgo and sand Hollow flows of the Frenchmen Springs Member of the Wanapum Basalt are informal names; however, they will be used in this paper.

\section{PREVIOUS WORK}

Warren and others (1945) completed a reconnaissance map of northwestern oregon which was published as part of an oil and gas exploration project by the United States Geological survey. In 1946, warren and Norbisrath described the Tertiary sedimentary and volcanic rocks in the upper Nehalem River basin in their "stratigraphy of the Upper Nehalem River Basin, Northwestern Oregon". They described groups of rocks: Tillamook volcanics, marine sedimentary formations, and the Columbia River basalt. In northwestern Columbia County, the marine strata include the upper Eocene tuffaceous mudstones of the Keasey Formation, which had previously been named by Schenck (1927), the late Eocene to Oligocene Pittsburg Bluff Formation, and the 
Oligocene to mid-Miocene scappoose Formation named by warren and Norbisrath (1946). They described the Pittsburg Bluff Formation as composed of a fine grained, fossiliferous, marine sandstone which interfingers with fine grained brackish water to deltaic, sandy, tuffaceous beds which are overlain by the scappoose Formation.

\section{Scappoose Formation}

warren and others (1945) described a molluscan fauna of "Blakeley" age from a composite section which they believed to overlie beds of the Pittsburg Bluff Formation about $3 \mathrm{~km}$ north of Buxton, Oregon. Warren and Norbisrath (1946) described these Oligocene to early Miocene tuffaceous sandstone and shale beds capped by the Columbia River Basalt Group, in the vicinity of Buxton, oregon and named them the scappoose Formation. They gave no type locality but described the scappoose formation as best exposed along the South Fork of Scappoose creek and at Rocky Point, southeast of the town of scappoose, oregon. They did not lithologically differentiate the scappoose formation from the underlying Pittsburg Bluff Formation because of the great similarity in rock types. The distinction was made on the basis of a distinctly different fauna, in what they believed to be the Scappoose Formation, which was correlated with fauna of the sooke Formation. 
Warren and Norbisrath (1946) described a cobble to boulder conglomerate composed of basic basalt clasts as the base of the scappoose Formation north of Buxton, oregon and northeast of Vernonia, Oregon. They described the scappoose Formation as overlying the Pittsburg Bluff Formation and separated from it by a conglomerate of variable thickness. Van Atta and Kelty (1985) describe the basal beds of the scappoose formation as generally containing pebble to boulder conglomerate. They found a conglomerate near the base of the formation at Oak Ranch creek, Cedar Creek, the railroad cut at Buxton, and along the North Fork of the Nehalem River. Near Scofield and at Lindsay Lake, the conglomerate is found beneath the flows of the Grande Ronde Basalt (Figure 2).

Basalt clasts in the conglomerate described by van Atta and Kelty (1985) have the same major oxide, minor, and trace element geochemistry as the mid-Miocene flows of the Columbia River Basalt Group (Kelty, 1981). Therefore, Van Atta and kelty (1985) concluded that deposition of the Scappoose Formation must have been coeval with the outpouring of the Columbia River Basalt Group and revised the age of the scappoose Formation to mid-Miocene (Figure 3). They suggest the discrepancy between their age for the scappoose Formation and that of Warren and Norbisrath (1945), may have occurred because of long covered intervals within the Warren and Norbisrath (1946) composite section. Since the 


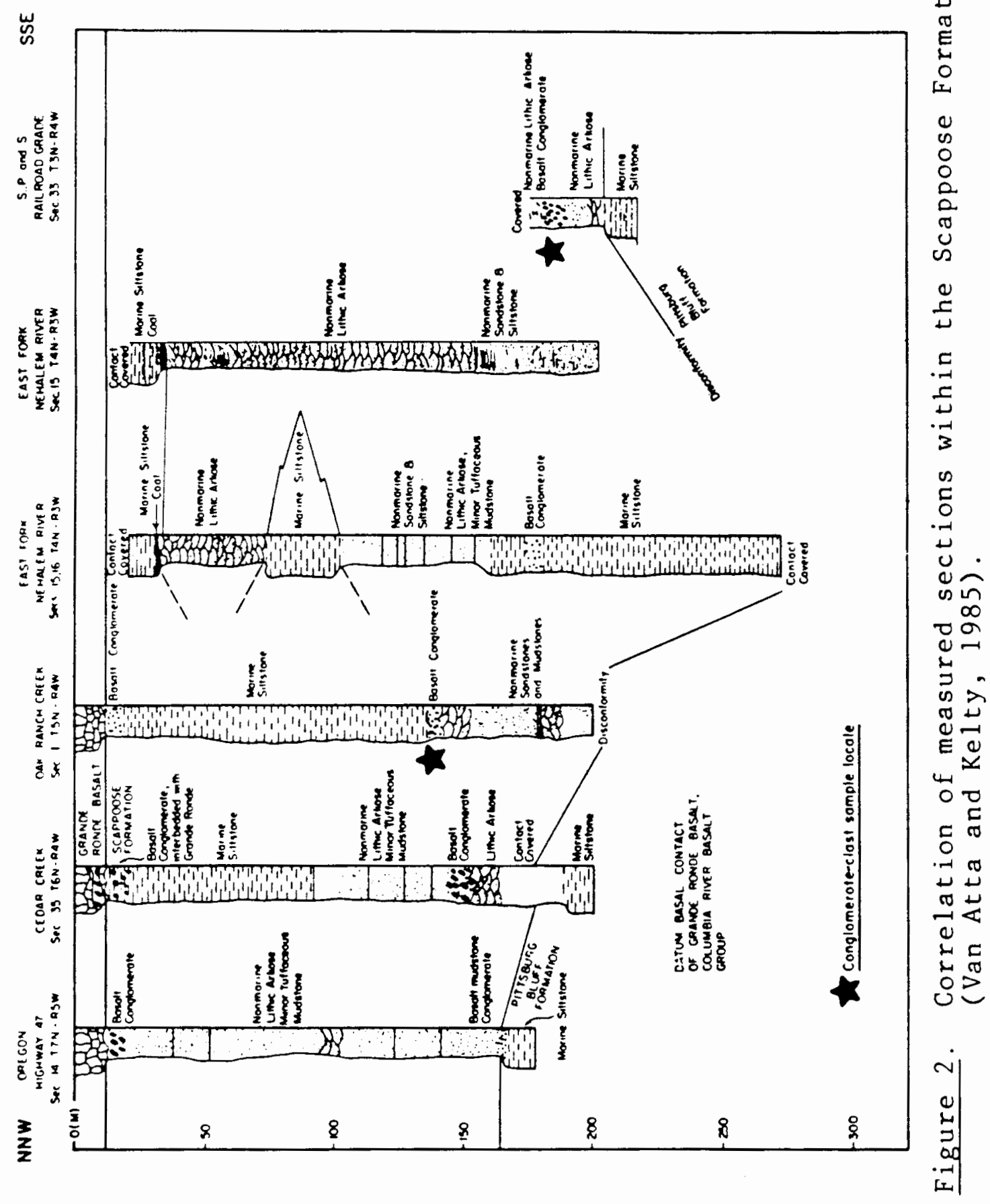




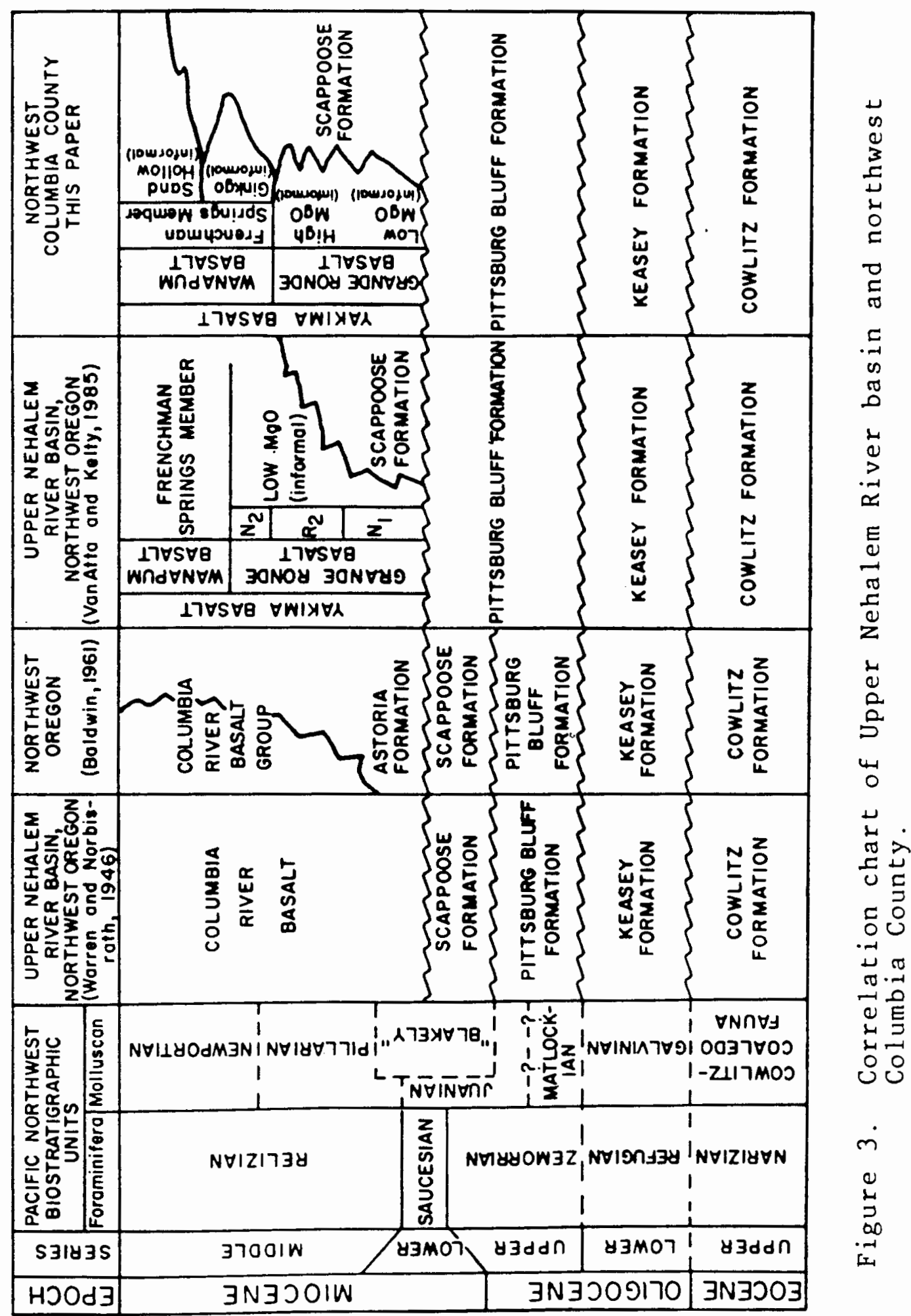


Warren and Norbisrath (1946) distinction between the scappoose and Pittsburg Bluff Formations was based on faunal assemblages rather than lithologies, the fauna may have come from the lithologically similar underlying Pittsburg Bluff Formation.

Niem and others (1985) prepared a geologic map of Clatsop County as part of an oil and gas study conducted for the Oregon State Department of Geology and Mineral Industries. The geology of the northeastern part of the county is based in part on the work of Coryell (1977), Cooper (1980), and Murphy (1981). They show the "Cannon Beach" member (informal) of the Astoria Formation underlying and coeval with the Columbia River Basalt Group and sedimentary interbeds within the Columbia River basalt flows.

Van Atta (1971) petrographically distinguished lithologic variations of the Tertiary sedimentary rocks in the upper Nehalem River basin including the Scappoose and Pittsburg Bluff Formations. He found the sandstone of the scappoose Formation contains more quartz and less silt than those of the Pittsburg Bluff Formation. Kelty and others (1980) made a reconnaissance map of northwestern Columbia County as part of a study for Northwest Natural Gas Company, Diamond Shamrock Company, and Reichhold Energy Corporation. Kelty (1981) described the lithofacies of the scappoose Formation and divided it into lower and upper fluvial 
members (informal) and a middle marine member (informal). He found the scappoose Formation to be intercalated with and overlain by flows of the Columbia River Basalt Group. Kadri (1982) described the basalt and mudstone conglomerate, micaceous sandstone and siltstone underlying and intercalated with the Wanapum Basalt at Clatskanie Mountain and correlated them with the informal upper member of the Scappoose Formation as defined by Kelty (1981). Because he considered these rocks stratigraphically equivalent to the mid-Miocene rocks exposed in clatsop county, he called them the Astoria Formation.

\section{Columbia River Basalt Group}

The Columbia River Basalt Group is a thick sequence of tholeitic flood basalts erupted from vents in oregon, Washington, and Idaho which covered some $162,000 \mathrm{sq} \mathrm{km}$ (Reidel and Tolan, personal communication, 1986). They were erupted between 16.5 and 6 million years ago (Mckee and others, 1977). Through mapping and geochemistry, stratigraphic units were identified (Waters, 1961; Mackin, 1961). Since then, further stratigraphic refinements have been made in identifying individual cooling units. Swanson and others (1979) revised the nomenclature for the columbia River Basalt Group.

Snavely and others (1973) suggested the coastal basalts of oregon and washington were geochemically similar 
to the plateau derived basalts but were erupted from a narrow belt of volcanic centers along the present-day oregon and washington coasts. Beeson and others (1979) proposed that the coastal basalts of Pack sack Lookout, the Depoe Bay Basalt, and the Cape foulweather Basalt are flows of the Columbia River Basalt Group which flowed to the coast from their vents in eastern oregon and washington and western Idaho rather than erupting from local coastal vents. They suggested that the more dense basalt had invaded the wet sediments. Beeson and others (1985) described the flows and distribution of the Frenchman Springs Member of the wanapum Basalt (Figure 4).

Kadri and others (1983) used major and trace element analysis to analyze the provenances of the Cowlitz, Keasey, Pittsburg Bluff, and Astoria Formations (Scappoose Formation of this paper; Figure 5). Their analyses showed that sodium (Na), potassium (K), lanthanum (La), samarium (Sm), and thorium ( $T h$ ) are important elements in characterizing these formations and their provenances.

The Cowlitz Formation is characterized by a higher $\mathrm{La} / \mathrm{Sm}$ ratio and higher concentrations of $K$ and $T h$ than the overlying Keasey Formation. The Pittsburg Bluff Formation has higher concentrations of $K$ and $N a$ than the Keasey Formation but the concentration of $T h$ is less than that of the Cowlitz Formation. The Astoria Formation is characterized by a higher concentration of sc than underlying rocks. The 


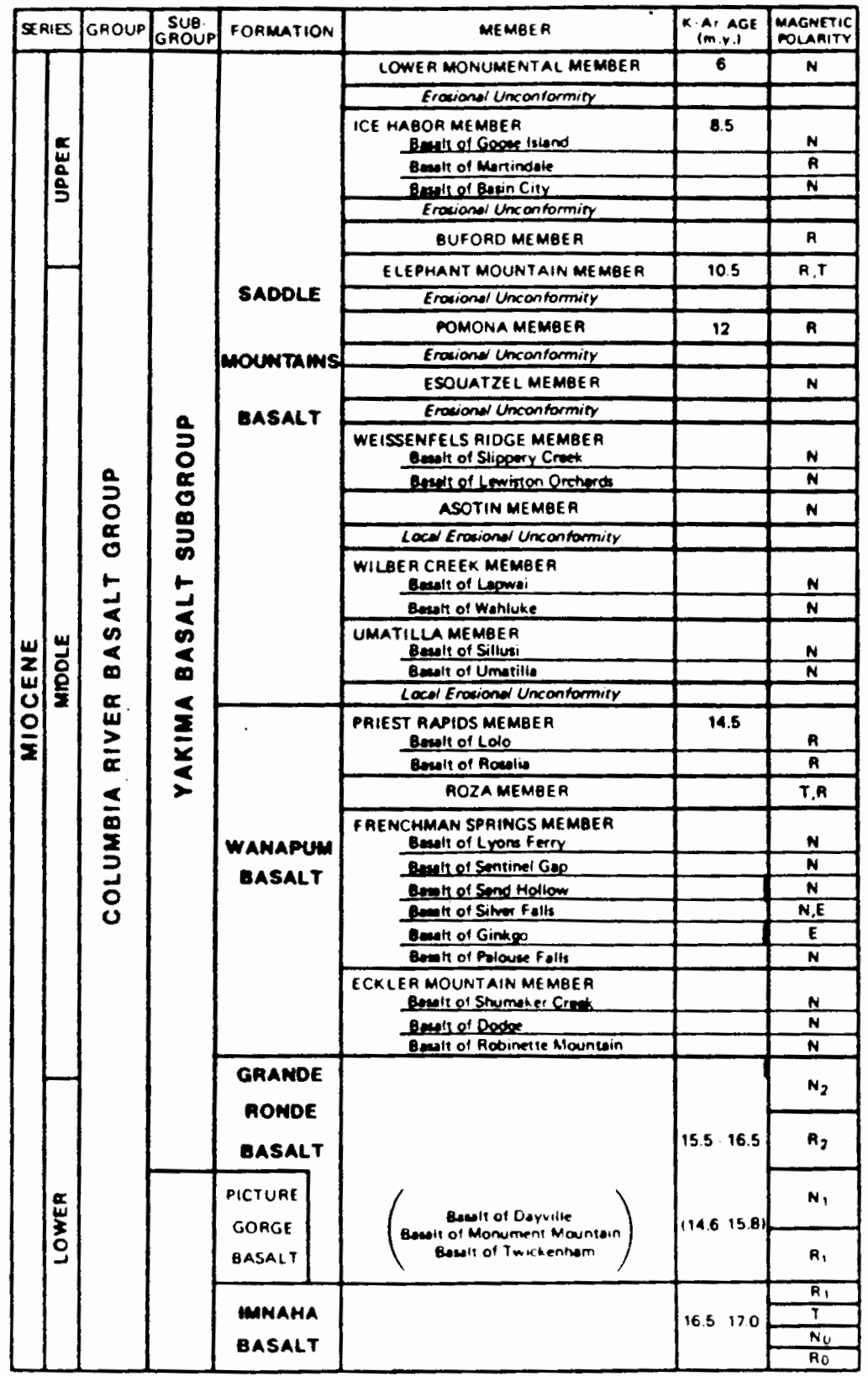

Figure 4. Columbia River Basalt Group stratigraphy in western oregon and washington (Beeson and others, 1985). Dark lines indicate flows present in study area. 

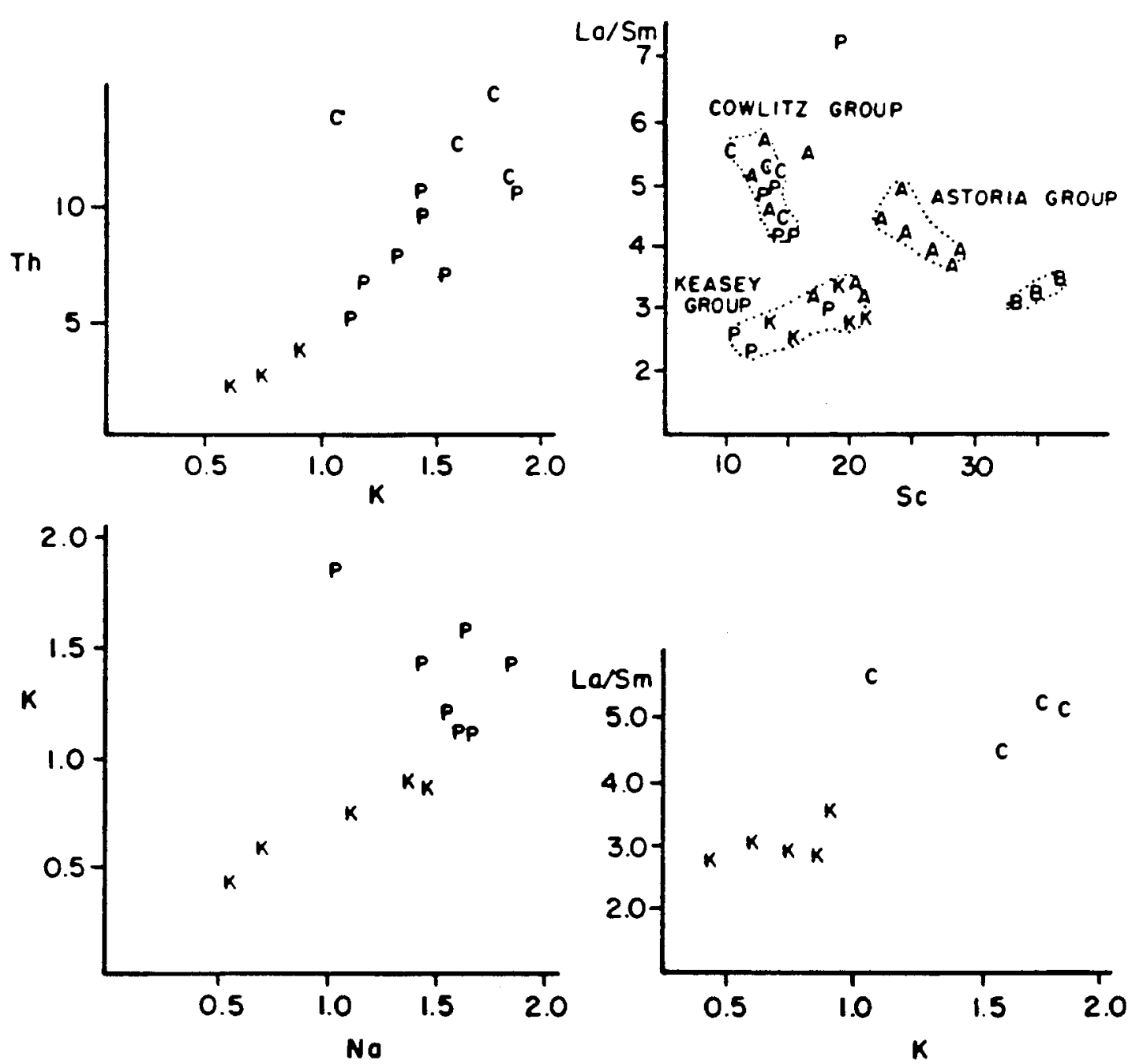

B COLUMBIA RIVER BASALT

A ASTORIA FORMATION

$P$ PITTSBURG BLUFF FORMATION

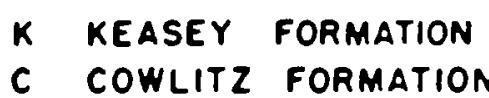

C COWLITZ FORMATION

Figure 5. Plots of some minor and trace elements that characterize some sedimentary formations in northwestern oregon (Kadri and others, 1983). 
Columbia River Basalt Group also has high Sc concentrations.

Kadri and others (1983) found their geochemical analyses substantiated petrographic and field work previously done. The higher $T h$ and $K$ values as well as the higher La/Sm ratios substantiated Van Atta's (1971) interpretation of a granitic and metamorphic provenance for the cowlitz Formation. The lower $\mathrm{K}, \mathrm{Th}$, and La/Sm values obtained for the Keasey Formation indicate a greater influence of volcanism on the provenance of the Keasey formation when compared to the cowlitz formation. The high sc concentrations of the Astoria Formation are most likely due to the influence of Columbia River Basalt Group on the provenance. 


\section{REGIONAL GEOLOGY}

The northern Coast Range physiographic province is composed of thick sequences of Tertiary sedimentary and volcanic rocks.

The oldest rocks in the northern coast Range are the mid-Eocene oceanic floor Siletz River Volcanics (Armentrout, 1983). These are overlain by the late Eocene Tillamook Volcanics which are believed to be seamounts formed on top of tholeiitic oceanic basalt (Duncan, 1982). The Tillamook volcanics correspond to the upper part of the siletz River Volcanics in the central coast Range (Armentrout, 1983). Sedimentary rocks were deposited in a eugeosynclinal trough which ranged from the klamath Mountains to Vancouver Island with local uplifts forming shallow basins.

The geologic history of northwestern oregon has been dominated by the interactions of the Juan de Fuca plate, the Pacific Plate and the North American Plate over approximately the last 50 million years (Drake, 1982).

From the late Eocene to mid-Miocene, active margin tectonism and sedimentation contributed material to the shallow basins. The Western Cascades began contributing volcaniclastic sediments to the basins in the early oligocene resulting in unconformable contacts along the 
structural highs and conformable contacts in the depositional basins (Armentrout, 1983).

Armentrout and suek (1985) hypothesized that, in the Eocene, the subduction zone that may have been under the present-day Cascades jumped to the west creating a hiatus in volcanism and allowing the deposition of the arkosic "Clark and Wilson Sand" (informal) of the Cowlitz Formation. These are the reservoir sands in the Mist Gas Field. In the early to mid-Miocene, regional tectonism occurred resulting in differential deformation and uplift which produced erosion and the eruption of the columbia River Basalt Group flows in the Columbia Plateau. These basalts flowed westward to the coast and invaded the sediments and became interbedded with the marine and fluvial coastal sediments (Beeson and others, 1979).

In the late Miocene, the Coast Range was further deformed and deposition became restricted to local downwarps and river valleys (Armentrout and Suek, 1985).

\section{REGIONAL STRUCTURE}

The major structural features in northwestern oregon (Figure 6) are the northeastern-plunging Nehalem Arch (Armentrout and Suek, 1985) and the Columbia River downwarp. The Columbia River downwarp is formed between the Nehalem Arch and the southeasterly-plunging Willapa Hills uplift in southwestern washington (Armentrout and Suek, 


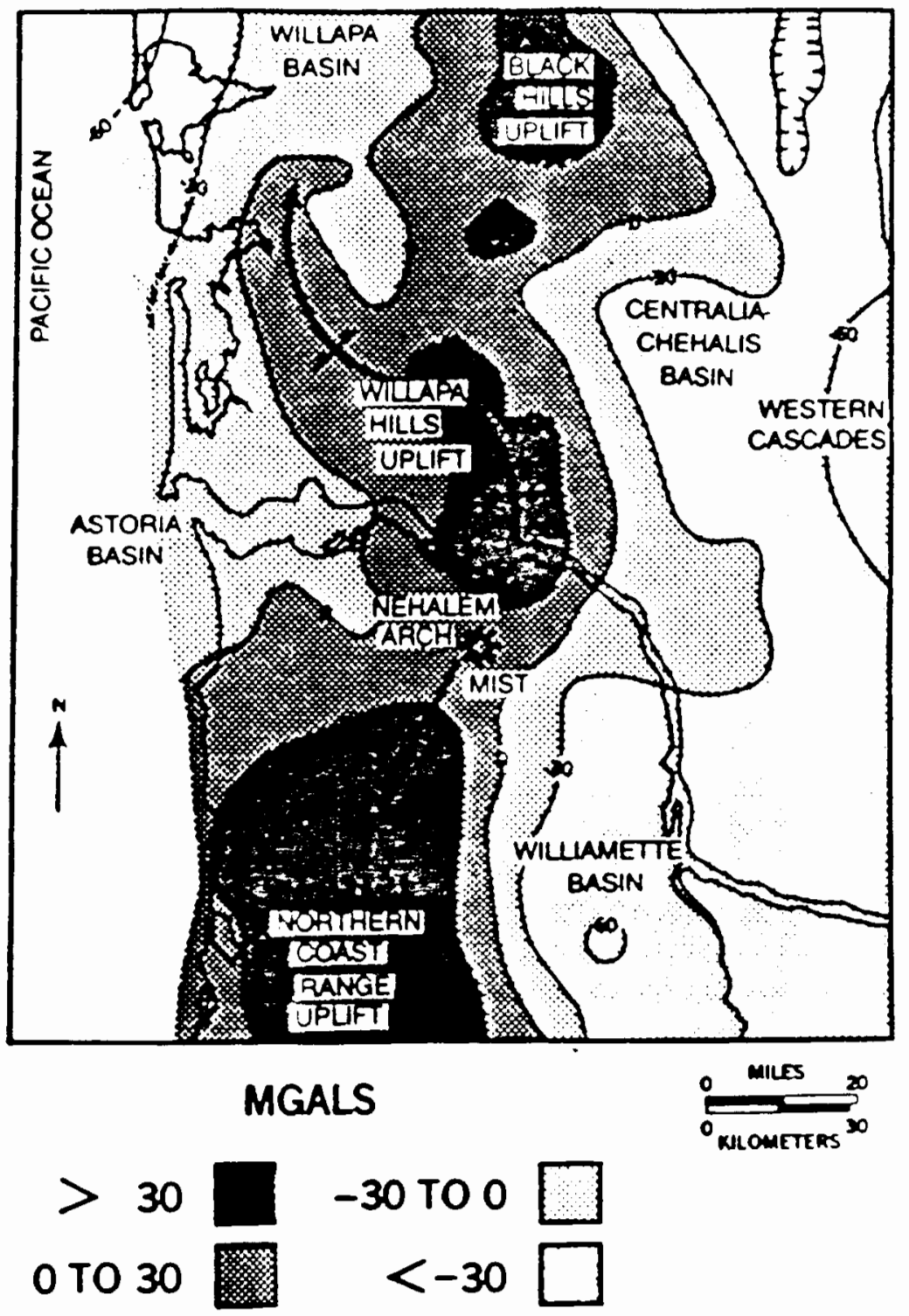

Figure 6. Regional Bouguer gravity anomaly for northwest Oregon and southwest Washington (Armentrout and Suek, 1985). 
1985). Superimposed on the Nehalem Arch are large, broad, northwest-southeast trending subparallel folds (Newton, 1976 ).

Fault trends are northeast, northwest, or east and west. The northwest faults may be related to the Portland Hills lineament to the southeast (Alger, 1985). Drilling at Mist shows most of the major faults seem to be truncated at the unconformity between the Cowlitz and Keasey formations indicating active tectonism in the late Eocene (Alger, 1985). Most of the faults exposed at the surface have a northwest-southeast trend. However northsouth, northeast-southwest, and some east-west trends are also apparent.

Paleomagnetic data indicate that the coast Range has undergone up to 70 degrees of rotation in a clockwise direction with the axis of rotation located in either the Klamath Mountains or near the Columbia River (simpson and Cox, 1977). Wells (1984) believes most of the rotation postdates the deformation of the coast Range caused by microplate collision and accretion to the continent. He ascribes the rotation to shear and asymmetric intracontinental extension across the northern Basin and Range. Heller and others (1985), through their petrographic analysis of the sandstone of the Tyee Formation, have developed a model that places the oregon coast Range basin farther east than at present, in what is now eastern oregon and Nevada. They 
hypothesize that the rotation of the oregon Coast Range and the Klamath Mountains moved westward to their present positions during the extension that occurred during the formation of the Basin and Range. 
STRATIGRAPHY

KEASEY FORMATION

The Keasey Formation, consisting of fossiliferous mudstone is the lowest stratigraphic unit in northwestern Columbia county. It crops out northwest of Mist, oregon. In this area, it is exposed in section $11, T .6 \mathrm{~N}, \mathrm{R}, 5 \mathrm{~W}$. along the Longview Fibre Mainline. The base of the formation is not exposed. It forms resistant beds which are deeply weathered, and all the primary structures have been destroyed by weathering; however, the fossils are preserved. The smectitic clays in the Keasey formation form a distinctive pea-sized detritus (Van Atta, 1971). In northwestern Columbia county, the Keasey Formation is the only sedimentary unit that is not micaceous. The dark brown mudstone weathers to a light buff color. Ledge forming concretions which are very distinctive in the Keasey formation along the Nehalem River south of Vernonia are not present in northwestern columbia county.

The contact with the overlying Pittsburg Bluff Formation is not exposed in this area.

\section{PITTSBURG BLUFF FORMATION}

The late Eocene to Oligocene Pittsburg Bluff Formation, which disconformably overlies the Keasey Formation, 
is approximately 200 meters thick and consists of two distinct lithologies which crop out in northwestern columbia County: very fine grained lithic arkosic sandstone; buff colored silty sandstone to sandy siltstone with white tuff beds. The Pittsburg Bluff Formation is deeply eroded in the study area and is disconformably overlain by the midMiocene sandstone and siltstone beds of the scappoose Formation or flows of the mid-Miocene Columbia River Basalt Group.

The sandstone of the lower part of the Pittsburg Bluff Formation crops out near the clatsop county-Columbia county line, T. $7 \mathrm{~N}$. R. $5 \mathrm{~W}$ in section 8 . It consists of very fine grained, well stratified, blue-gray, fossiliferous, lithic arkosic to arkosic sandstone beds. The sandstone is moderately to well sorted with subrounded to subangular grains. It overlies thick beds of fossiliferous brown siltstone displaying slabby weathering.

The fine grained sandstone beds are interbedded with a coarse, red, hematite cemented, poorly sorted sandstone. The red, sparsely fossiliferous, coarse grained sandstone is composed of fine grained sand, and volcanic pebbles. The fine material within this coarse grained bed was probably derived from a mixing of this bed with the fine grained sandstone by bioturbation. The sandstone underlies beds of micaceous and fossiliferous sandy siltstone with tuffaceous and sandy interbeds. 
The siltstone beds, which compose the upper part of the Pittsburg Bluff Formation, are best exposed along oregon Highway 47 north of Mist and in the cliffs west of Fishhawk Lake. This unit is extensive and in the northern part of the study area, south of U.S. Highway 30 , forms precipitous bluffs such as skunk Cabbage Ridge. Weathering produces detrital chips. The siltstone typically displays blocky jointing. Round burrows $(4-5 \mathrm{~cm}$ in diameter) filled with silt are common in the siltstone as are lenses of mollusk shells. Concretions present in the type locality along the banks of the Nehalem River, near Pittsburg, Oregon, are absent in northwestern Columbia county.

Near the top of the siltstone member (informal) along Joe Flora Road on Clatskanie Mountain, the siltstone member is capped by a very poorly sorted, bioturbated, distinctive red bed. The grains are silt to pebble sized, and the bed is topped by Frenchman springs Member basalt flows. In section $27, T .7 N . R 5 W$. , the red bed is overlain by a mudflow with basaltic boulders. The mudflow is disconformably overlain by Frenchman springs Member basalt flows in section $26, T .7 N . R$. $5 \mathrm{~W}$. In section $11, T .6 \mathrm{~N} . \mathrm{R}, 5 \mathrm{~W}$, , the top of the Pittsburg Bluff Formation is composed of fine grained, cross-bedded, interbedded arkosic sandstone and tuffaceous claystone beds with lenses of quartzite pebbles. Beds of organic material and lignitic wood fragments are common. 
Landsliding and slumping are common in the upper siltstone (Figure 7) as well as in the lower sandstone of the Pittsburg Bluff Formation. Along Ross Road, in the northwest corner of the study area, jumbled lithologies, gentle rounded topography, and landslide scars on the cliffs indicate landsliding. In section $11, T .6 \mathrm{~N} . \mathrm{R}$ 5., slumping can be observed.

The upper part of the Pittsburg Bluff Formation is traceable across northwestern Columbia county from the northwest corner to the area south of Clatskanie Mountain. This is an unusually large area to be underlain by the Pittsburg Bluff Formation which is subject to landsliding and deep weathering. The bluffs overlooking the Co? umbia River and Clatskanie Mountain are overlain by resistant flows of the Columbia River Basalt Group which appear to protect the rocks of the Pittsburg Bluff Formation from erosion. The areas where the basalt flows are not present are more deeply eroded than those overlain by the basalt.

SCAPPOOSE FORMATION

The Scappoose Formation in northwestern Columbia County overlies the Pittsburg Bluff Formation. The scappoose Formation exposed on Clatskanie Mountain is composed of basaltic conglomerate with an arkosic matrix, crosslaminated to cross-bedded, friable, quartz-rich arkosic to 


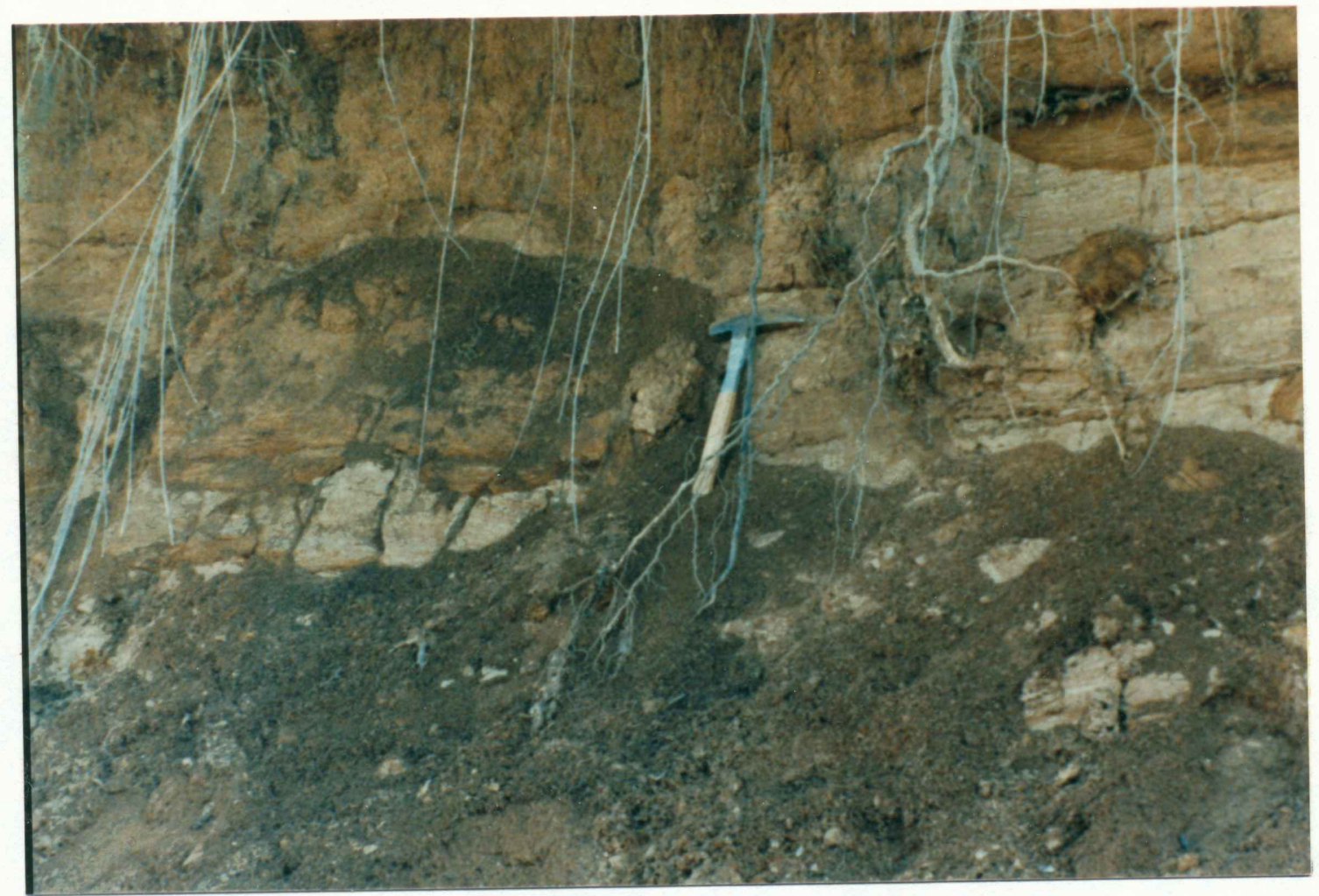

Figure 7. Cross-bedded, tuffaceous sandstones and siltstones of the Pittsburg Bluff Formation. Note slumping on the left. 
lithic arkosic sandstone, siltstone and mudstone (Figure 8). On Clatskanie Mountain, the scappoose Formation is separated from the Pittsburg Bluff Formation by a conglomerate with mudstone and basalt clasts (Figures 9 and 10). Without the underlying basaltic and mudstone conglomerate, the scappoose formation is lithologically indistinguishable from the underlying Pittsburg Bluff Formation. The lower basaltic conglomerate occurring near the base of the Scappoose Formation and the associated fluvial sandstone and siltstone that Van Atta and Kelty (1985) describe in areas to the southeast of the study area are present in northwestern columbia county as well.

The lowest part of the scappoose Formation in northwest Columbia county is exposed in sections 2 and $11, \mathrm{~T}$. 6N. R. 5W. on Clatskanie Mountain. The basal framework supported conglomerate is composed of palagonitic stringers, weathered, angular to subangular basalt clasts and mudstones in a quartz-rich micaceous arkosic sand matrix. The basalt clasts are deeply and spheroidally weathered. Vesicles may be observed in some of the clasts. The basalt clasts are composed of low MgO Grande Ronde Basalt (M. H. Beeson, personal communication, 1985).

The basaltic conglomerate is overlain by sandstone and siltstone beds which display various primary structures including cross-laminations, cross-bedding, planar crossbedding, and climbing ripples (Figure 11 ). 


\begin{tabular}{|c|c|c|c|}
\hline Unit & \multicolumn{2}{|c|}{$\begin{array}{c}\text { Column in } \\
\text { meters }\end{array}$} & Lithology \\
\hline $\begin{array}{l}\text { Columbio } \\
\text { River Basolt } \\
\text { Group }\end{array}$ & & & $\begin{array}{l}\text { Aphyric basalt pillows with orange } \\
\text { weathering rind. }\end{array}$ \\
\hline \multirow{5}{*}{$\begin{array}{l}\text { Scoppoose } \\
\text { Formotion }\end{array}$} & \multirow{5}{*}{ 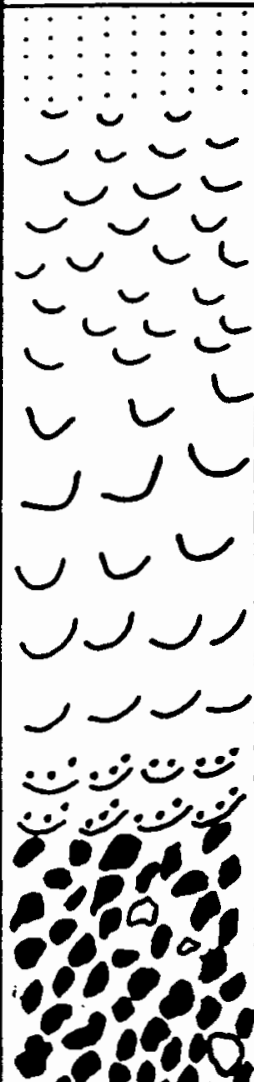 } & 2 & $\begin{array}{l}\text { Poorly sorted, micoceous, loosely consoli- } \\
\text { dated orkosic sand with mudstone rip-ups. }\end{array}$ \\
\hline & & 3 & $\begin{array}{l}\text { Very fine groined, poorly to moderotely } \\
\text { sorted, micoeous orkosic sand ond tuf- } \\
\text { foceous siltstone with lignitic wood. }\end{array}$ \\
\hline & & 10 & $\begin{array}{l}\text { Dark gray, tuffoceous, micaceous, fine } \\
\text { grained moderately sorted, lithic arkosic, } \\
\text { frioble sand with lignitic wood. }\end{array}$ \\
\hline & & 2 & $\begin{array}{l}\text { Well sorted bosaltic pebble sized con- } \\
\text { glomerate. }\end{array}$ \\
\hline & & 5 & $\begin{array}{l}\text { Framework supported bosaltic and mud- } \\
\text { stone conglomerate with micaceous } \\
\text { arkosic matrix, vessicular clasts with } \\
\text { spheroidal weothering. }\end{array}$ \\
\hline $\begin{array}{l}\text { Pittsburg } \\
\text { Bluff } \\
\text { Formation }\end{array}$ & & & \\
\hline
\end{tabular}

Figure 8 . Measured section along Longview Fibre MainIine on Clatskanie Mountain. 


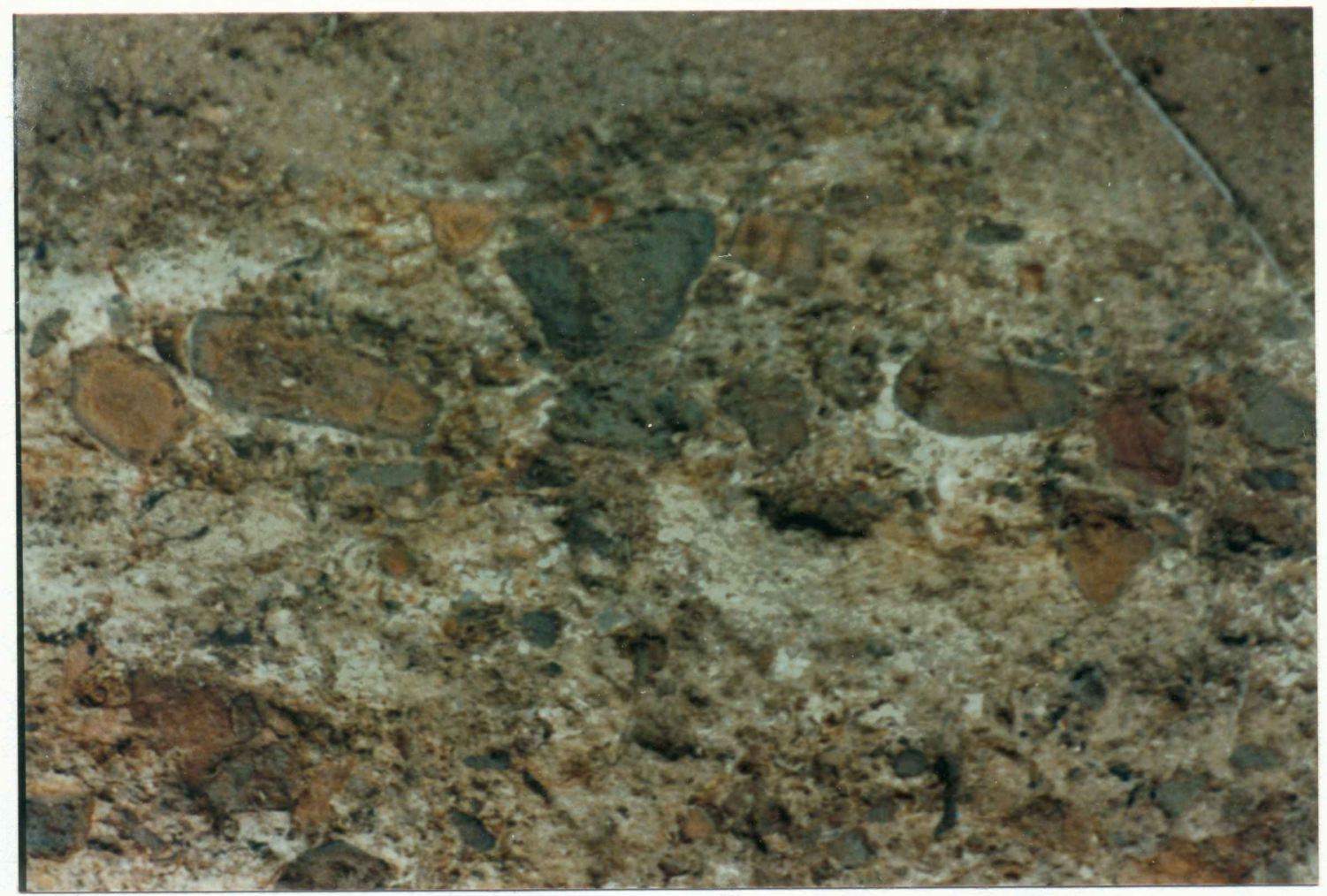

Figure 9. Mudstone and basaltic clast conglomerate at base of Scappoose Formation in Section 11, Township 6 north, Range 5 west. 


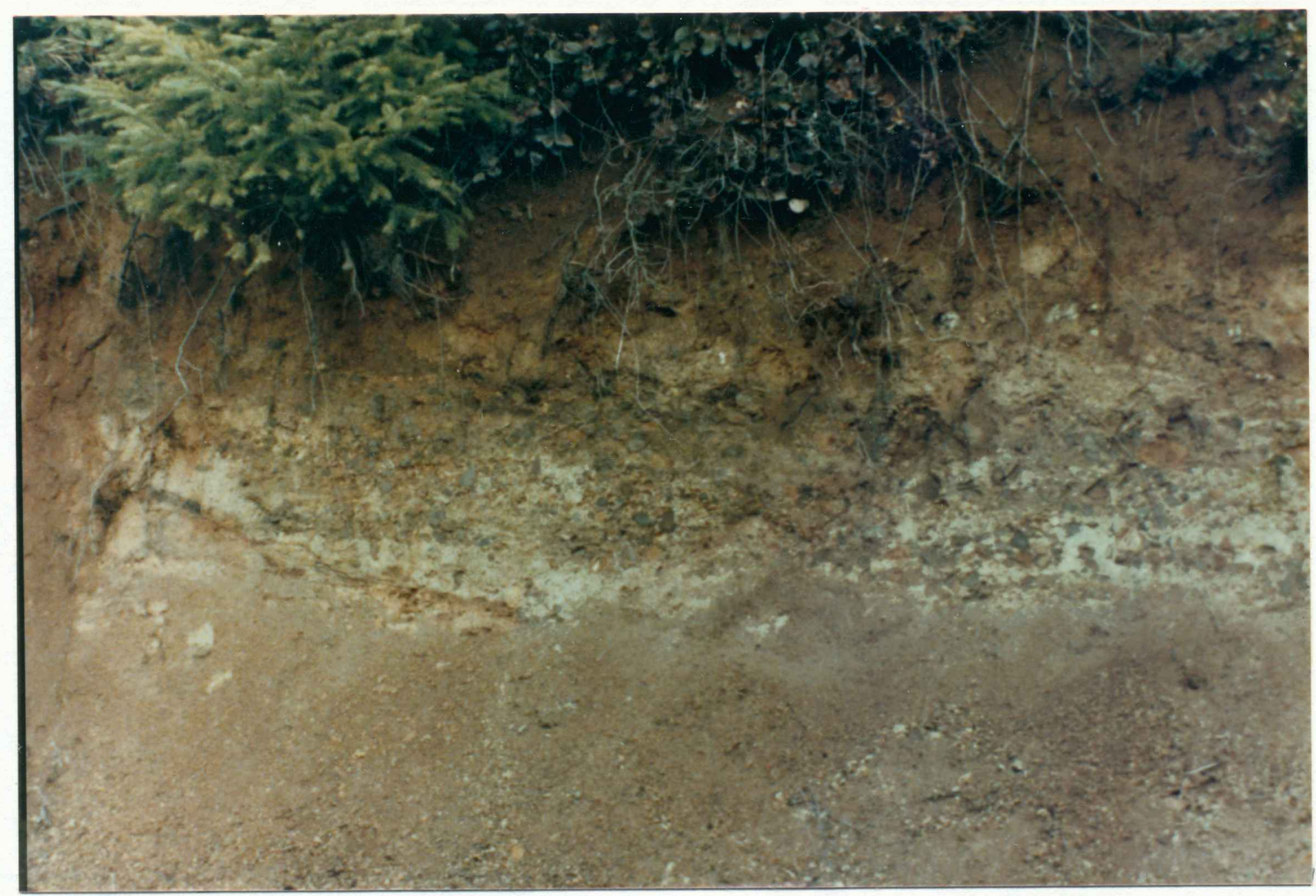

Figure 10. Basaltic conglomerate at base of Scappoose Formation on Clatskanie Mountain. 


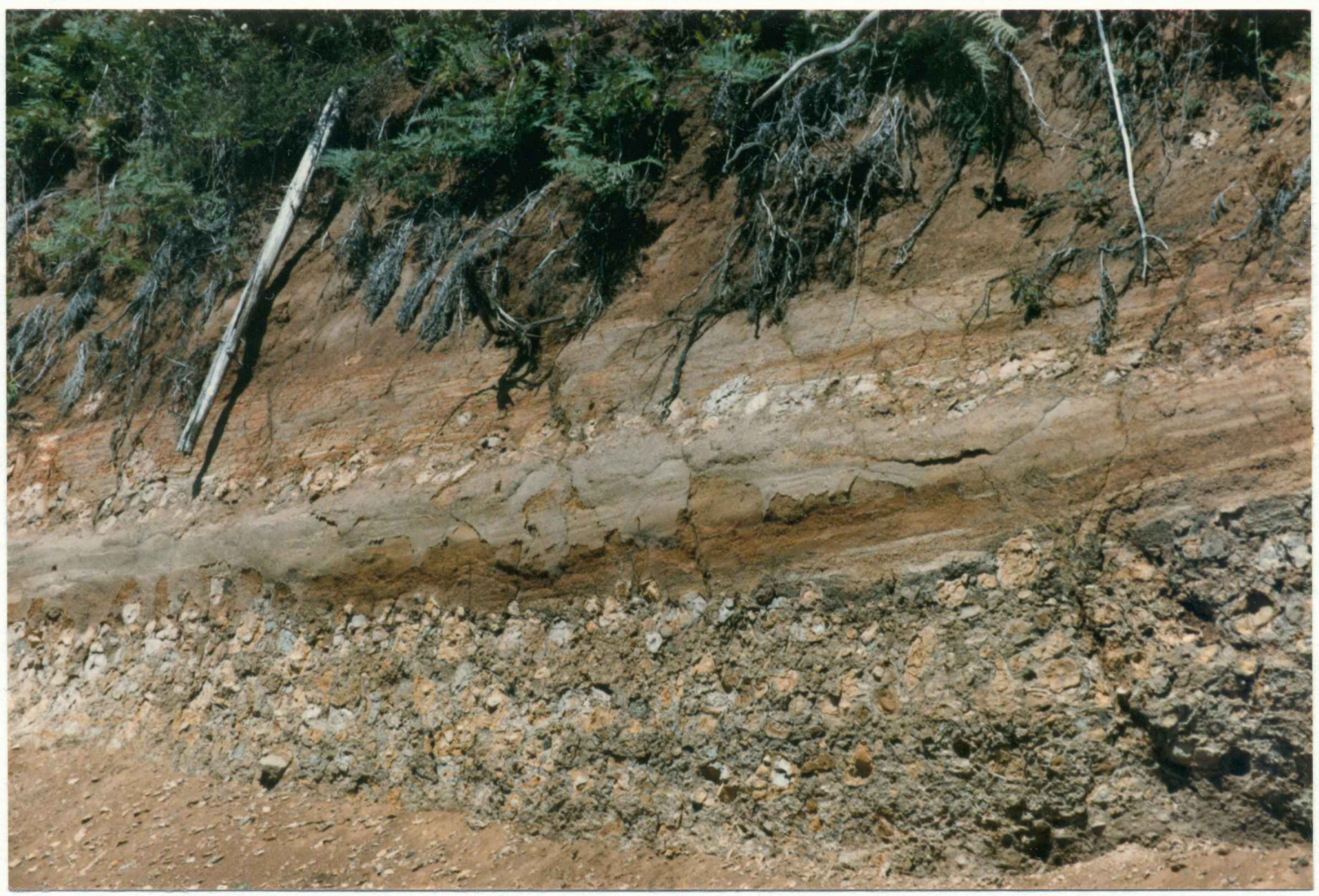

Figure 11. Cross-bedded arkosic sandstone overlying basaltic conglomerate. Located Section 2, Township 6 north, Range 5 west. 
The scappoose Formation is interbedded and intercalated with both the Grande Ronde Basalt and Frenchman Springs Member of the Columbia River Basalt Group. On Oregon Highway 47 and to the southeast of Mist, the Scappoose Formation is interbedded and intercalated with low Mgo flows of the Grande Ronde Basalt (Figure 12; Van Atta and Kelty, 1985).

In northwestern Columbia County, the scappoose Formation occurs beneath the Frenchman springs Member, as interbeds between basalt flows and on the margins of the flows. stratigraphically, the lowest interbed in northwestern Columbia County lies between a high Mgo Grande Ronde Basalt flow and a Ginkgo flow of the Frenchman springs Member. This interbed is exposed in the large quarry on clatskanie Mountain, to the west of clatskanie Mountain in the Fishhawk drainage, and on Tunnel Road. It is an orange, poorly sorted, micaceous, loosely consolidated, lithic arkosic sandstone. This bed is massive with random orientation of the mica. The sand grains are typically subangular to subrounded.

A second interbed, underlying a sand Hollow (informal) flow and overlying a Ginkgo flow, is a very distinctive light gray to white, faintly cross-bedded, quartz-rich arkosic sandstone. This bed crops out in section $27, T$. 7N. R. 5W. Very few grains of feldspar can be seen in hand specimen; however, the quartz grains are coated in clay 


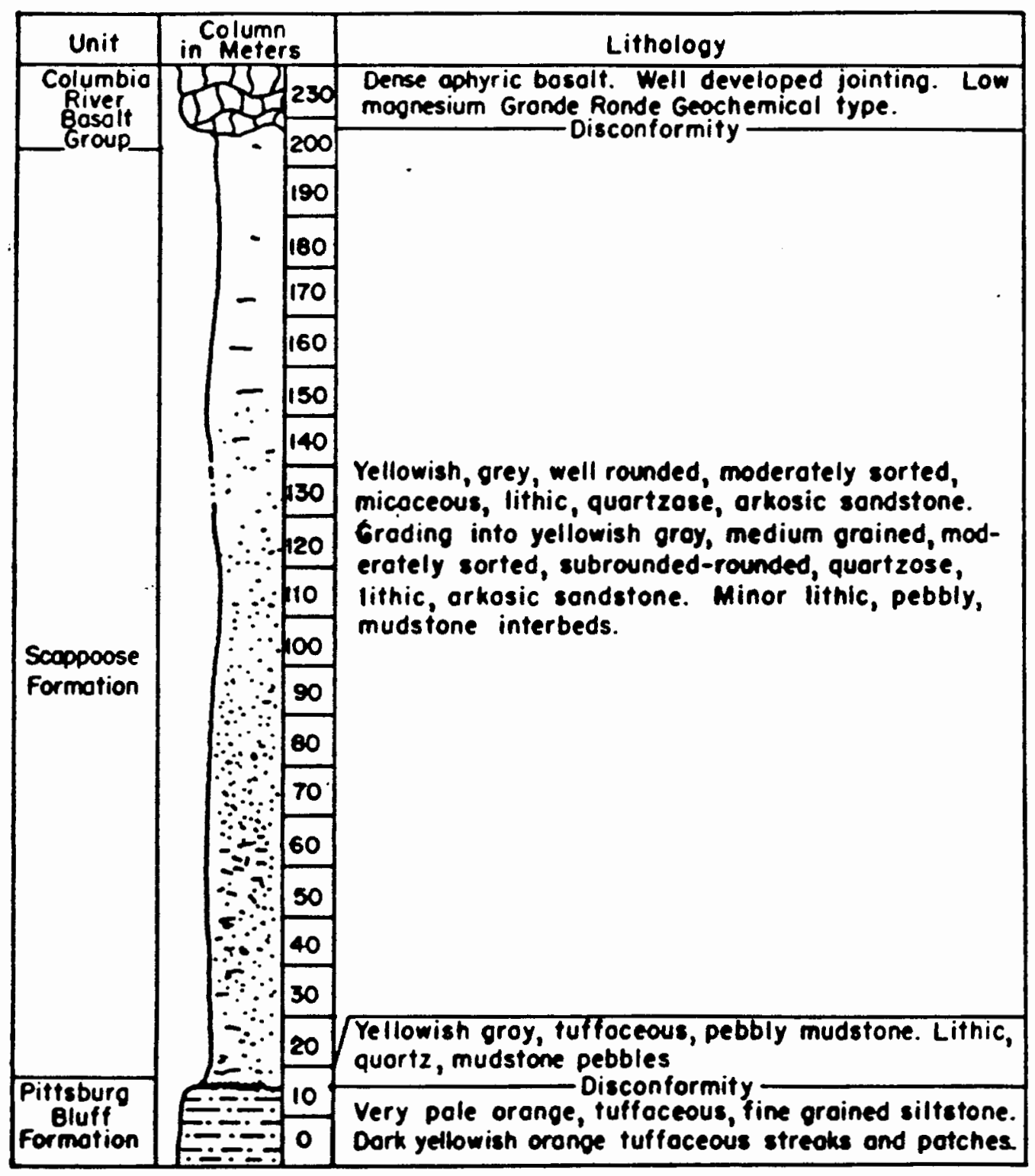

Figure 12. Measured section along oregon Hwy 47 south of Clatskanie, Oregon (Kelty, 1981). 
which probably formed as the result of weathering of the feldspar. There is very little matrix. The sandstone is loosely consolidated. There are thin, faint, cross laminae formed by thin (1-2 mm) beds of organic material. These are best seen in the rain when the outcrop is wet. The light gray sandstone is fine to medium grained, poorly to moderately sorted with angular to subangular grains. The sandstone is approximately 5 meters thick. No fossils were found. The contact with the overlying wanapum Basalt is exposed in the study area.

The scappoose formation sandstone and siltstone beds which occur marginally to the Frenchman Springs Member flows, crop out on clatskanie Mountain in northwestern Columbia County. They consist of poorly sorted, lithic arkosic, micaceous, sandstone and local siltstone. The sandstone is generally massive with randomly oriented mica while the siltstone is occasionally cross-bedded.

On Clatskanie Mountain, palagonitic breccia is locally encapsulated in massive arkosic sandstone of the scappoose Formation (Figure 13). The scappoose formation sandstone also appears as "plumes" in the basalt (Figure 14).

COLUMBIA RIVER BASALT GROUP

Five types of basalt flows of the Columbia River Basalt Group are present in northwestern Columbia County (marked with a dark line on Figure 4 ). There are three 


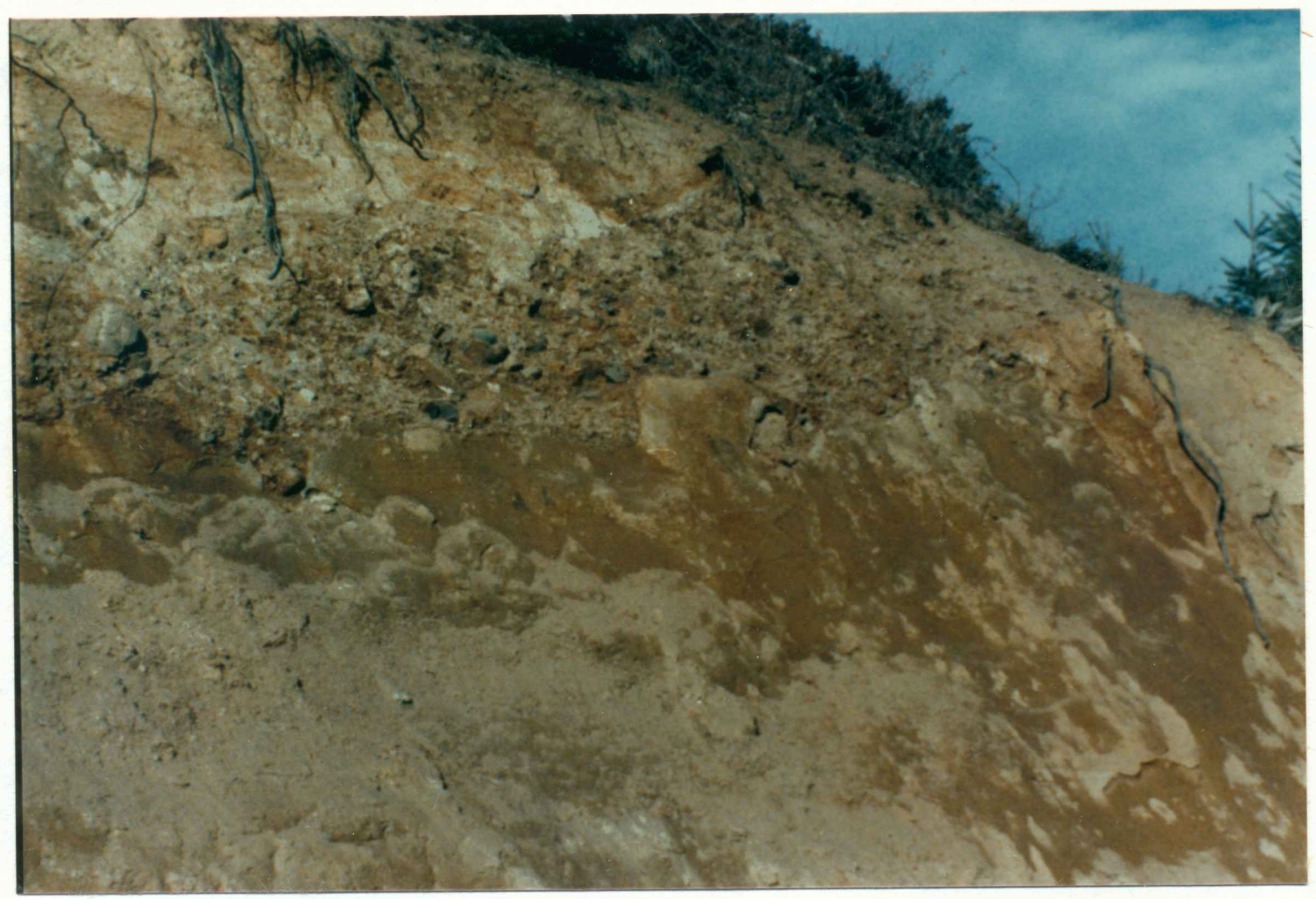

Figure 13. Frenchman Springs Member intercalated with sandstone of the Scappoose Formation. Located in Section 34, Tormship 7 north, Range 5 west. 


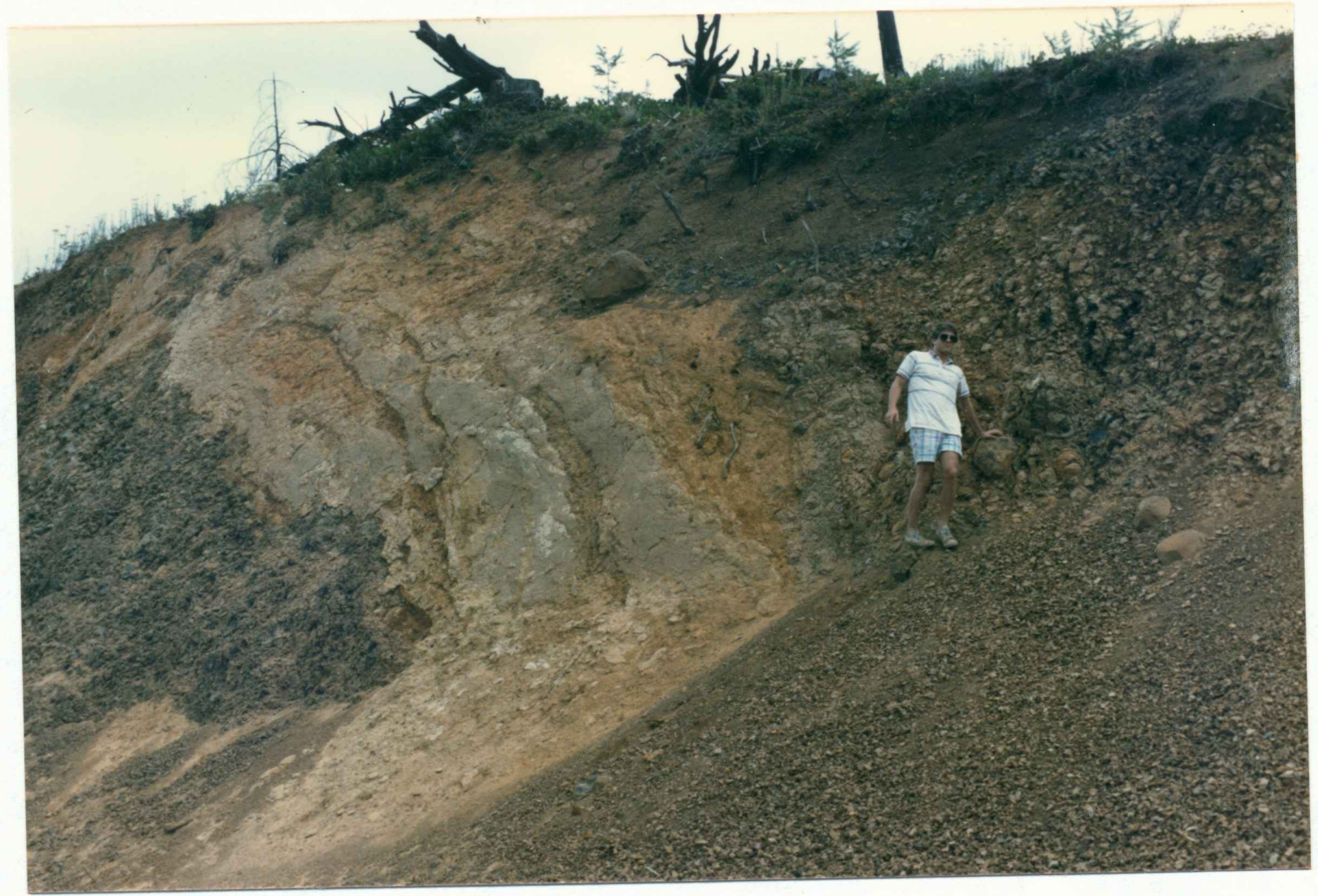

Figure 14. Sandstone of the Scappoose Formation forms "plume" in Frenchman Springs Member. Located Section 22, Township 7 north, Range 5 west. 
flows of the Grande Ronde Basalt. Two of the flows are of the low Mgo geochemical type and one flow is of the high Mgo type (see Geochemistry section). The Frenchman springs Member flows in the study area represent the Ginkgo and Sand Hollow units (Beeson and others, 1985). These flows are exposed in a large quarry in section $26, T .6 \mathrm{~N}, \mathrm{R}$. $5 \mathrm{~W}$. on Clatskanie Mountain.

Although it is possible to identify the basalt units based on field criteria, major oxide geochemistry is the best means of distinguishing between the flows. The Grande Ronde Basalt in hand sample is aphyric, light to dark gray with a brown weathering rind. The high MgO Grande Ronde Basalt flows appear to be slightly coarser grained than the low Mgo flows. The high Mgo flows sometimes are more open textured than the low Mgo flows.

The Frenchman springs Member flows in the study area typically have an orange weathering rind and locally show spheroidal weathering. The Ginkgo basalt flow is stratigraphically the lowest flow of the Frenchman springs Member in northwestern Columbia county. It is distinguished by numerous large, yellow, blocky shaped plagioclase phenocrysts, that may range in size from several millimeters to 2 centimeters in length, and an open textured groundmass. sand Hollow flows are variable in plagioclase phenocryst distribution. The phenocrysts are abundant in some flows 
and absent in others. In the study area, the sand Hollow basalt has few phenocrysts.

In northwest Columbia County, the Columbia River Basalt Group flows overlie either the Pittsburg Bluff Formation or the scappoose Formation. Northeast of clatskanie Mountain, and to the east in the Fishhawk Creek area, both the Grande Ronde Basalt and the Frenchman Springs Member flows disconformably overlie rocks of the Pittsburg Bluff Formation. On Clatskanie Mountain, the Frenchman springs Member flows overlie and are intercalated with sandstone and siltstone beds of the scappoose formation.

The Columbia River Basalt Group which crops out in northwestern Columbia County consists of breccias, pillows, and subaerial flows with incipient to well developed columnar to blocky jointing. The hyaloclastites, palagonite, breccias, and pillows generally underlie flows or are encapsulated within sandstone beds. The breccias and pillows generally make up relatively thin units beneath the subaerial portion of the flows.

The Ginkgo flow crops at the top of Joe Flora Road where it is in fault contact with the sand Hollow flow. It is separated from the sand Hollow flow by a thin $(1-2 \mathrm{~cm})$ claystone breccia.

The Grande Ronde Basalt and Frenchman Springs Member flows in the study area all show normal remnant magnetism. 
STRUCTURE

structures are not readily apparent in northwestern Columbia county due to lack of outcrop, vegetative cover and the friable nature of the sedimentary rocks.

The faults observed in the field have a $\mathrm{N} 50 \mathrm{~W}$ degree trend. One of the best field exposures is on the Longview Fibre Mainline at the intersection with Joe Flora Road. Here the Ginkgo flow is in fault contact with the underlying, stratigraphically higher, sand Hollow flow. A thin (1-2 cm) layer of brecciated claystone separates the two flows. Along Ford Creek, a rapid change in attitude indicates a northwest trending fault.

The beds in the mapped area generally strike northeast with the bedding planes gently dipping 5-10 degrees to the northwest. Rapid changes in attitude are common.

side looking radar imagery (SLAR) infra-red aerial photographs were examined for lineaments. Faults, which are generally seen as linear features, are classified by McDonald (1969) as persistent linears or offsetting linear patterns. The lineaments in the study area (Figure 15) are persistent linears. The lineaments trend northwest, northeast, and east-west. 


\section{GEOCHEMISTRY}

Eleven whole-rock sedimentary samples were analyzed by Dr. Peter Hooper of Washington state University, for major, minor, and trace element concentrations. Tables I and II list major and trace element concentrations of the Pittsburg Bluff, Scappoose and Astoria Formations.

The samples from the scappoose formation and the Astoria Formation were chosen on the basis of stratigraphic equivalency noted in the field.

All of the formations show overlap and a wide range of concentrations. Figures 15-17 are plots showing the concentrations of the elements which best discriminate between both the Astoria and Scappoose Formations and the Pittsburg Bluff Formation. Of the trace and minor elements, the rare earth elements (REE), best show the similarities of the Astoria and the Scappoose Formations, and how they differ from the Pittsburg Bluff Formation.

The Astoria and the scappoose formations generally tend to be enriched in the REE elements: lanthanum, cerium, samarium, europium, ytterbium. Both formations also show higher concentrations of scandium, titanium, aluminum, and potassium than the Pittsburg Bluff Formation. The Astoria and Scappoose Formations show lower concentrations of strontium, barium and sodium than the Pittsburg Bluff 


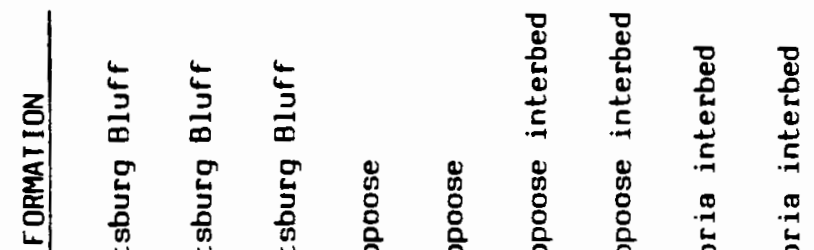

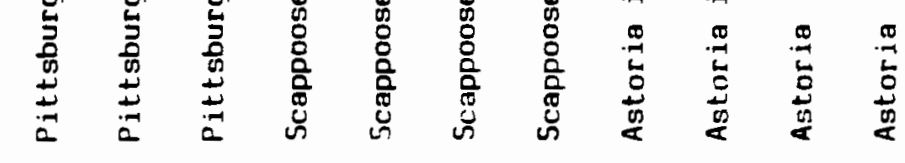

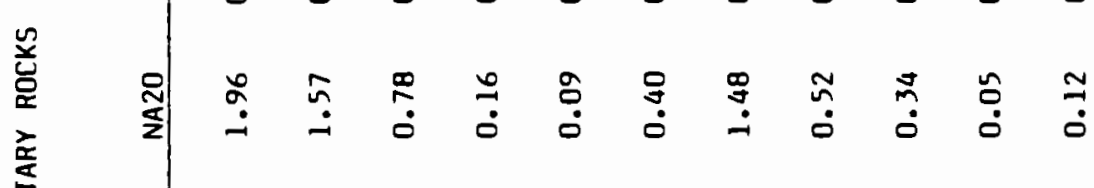

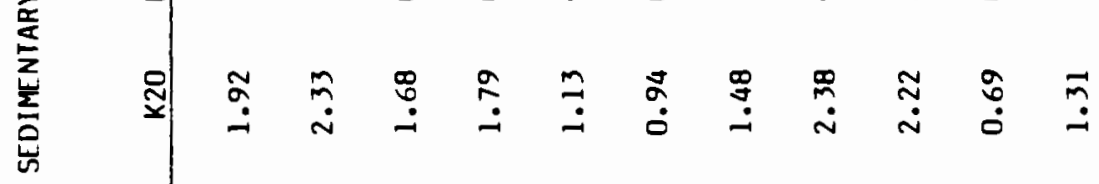

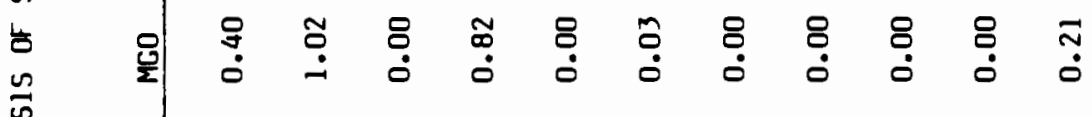

$$
\begin{aligned}
& \text { - }
\end{aligned}
$$

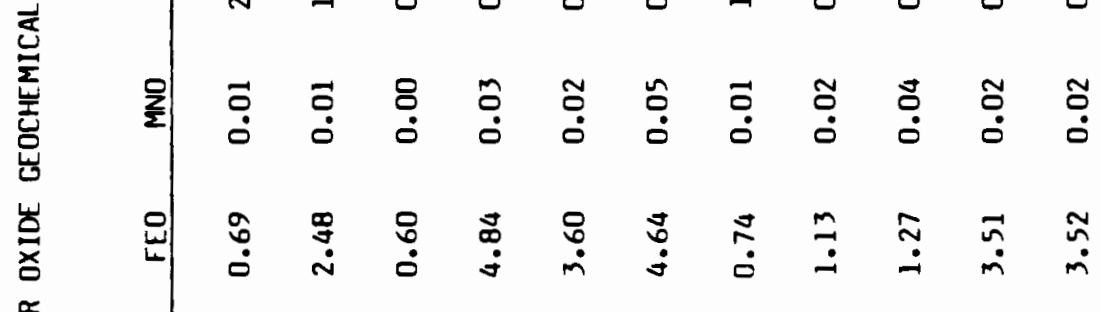

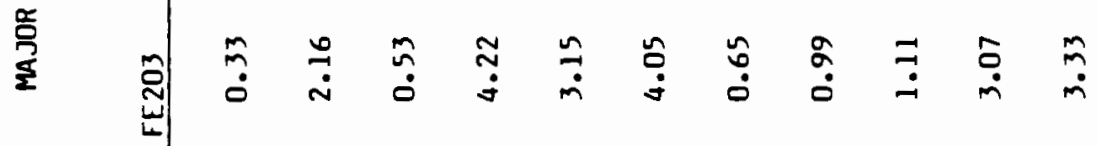

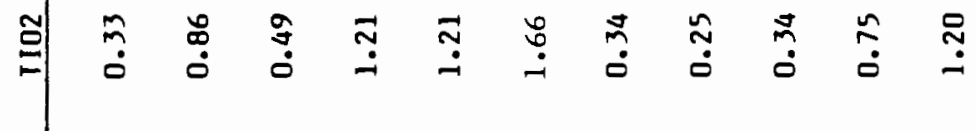

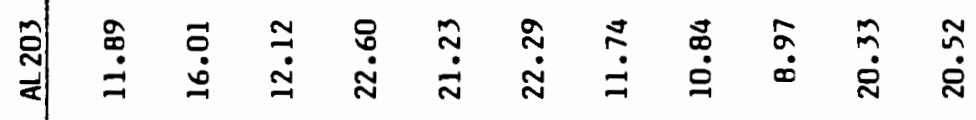

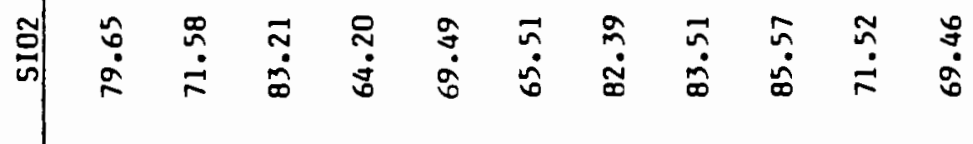

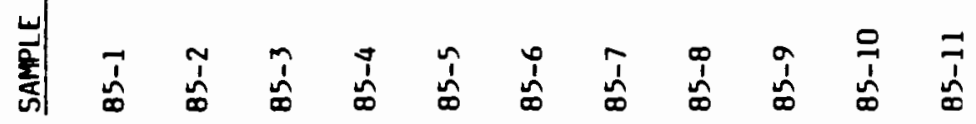




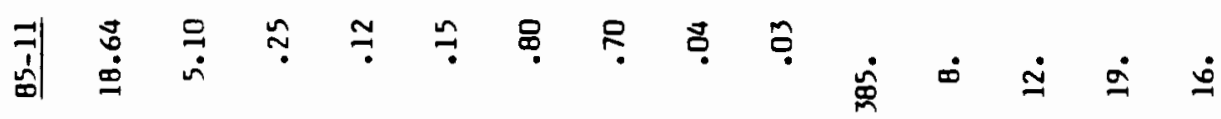

言

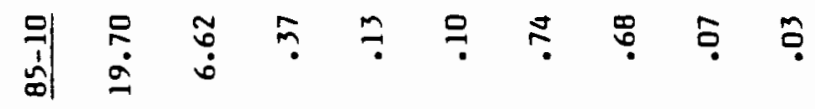

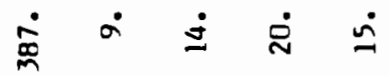

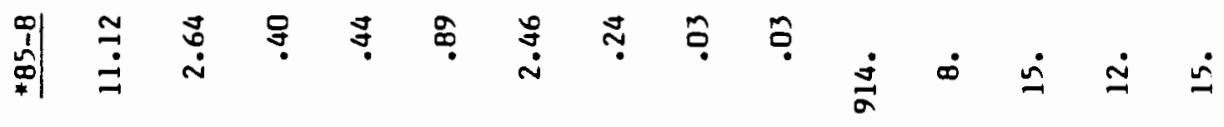

离|

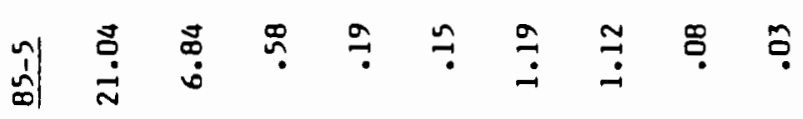

$\dot{\dot{g}} \dot{\infty} \dot{m} \dot{\sim} \dot{\jmath}$

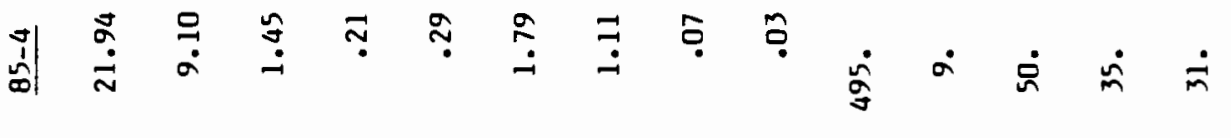

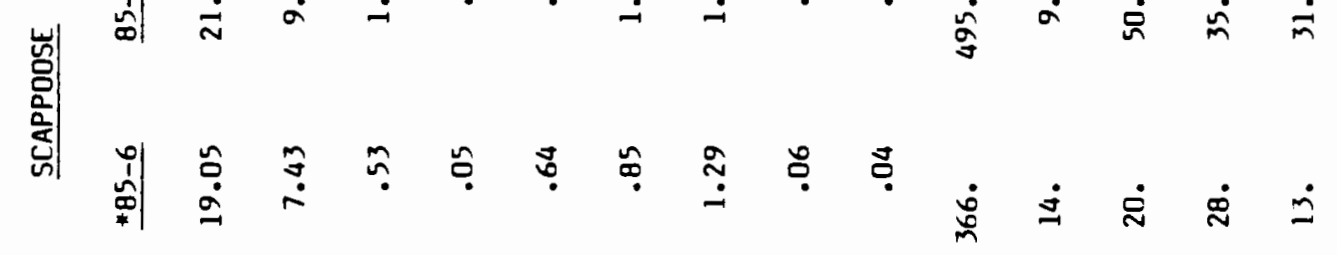

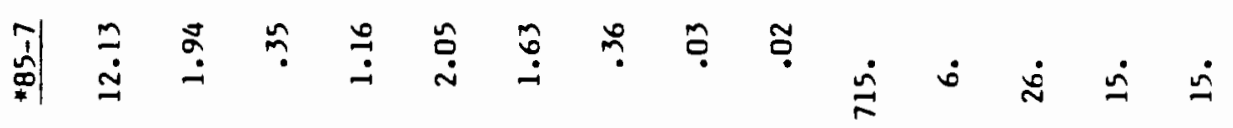

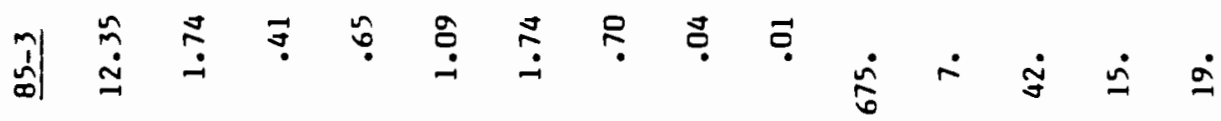

莺

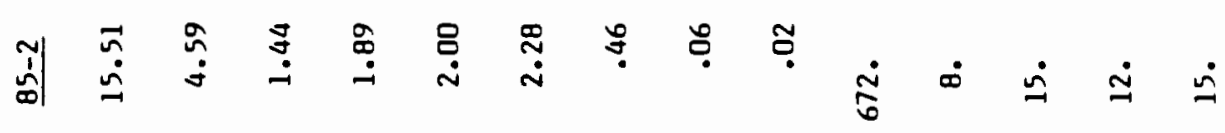

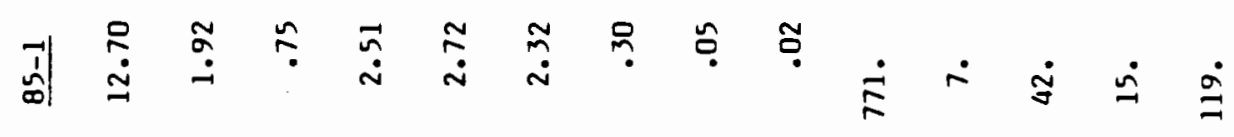

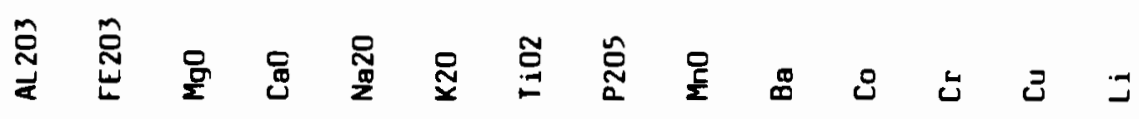




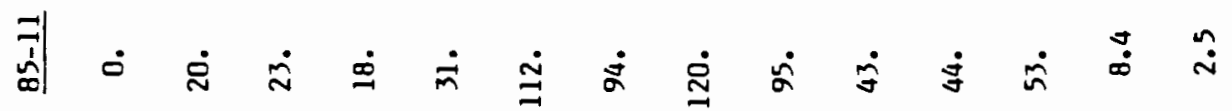

妾

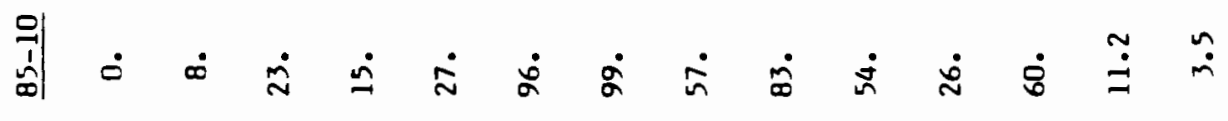

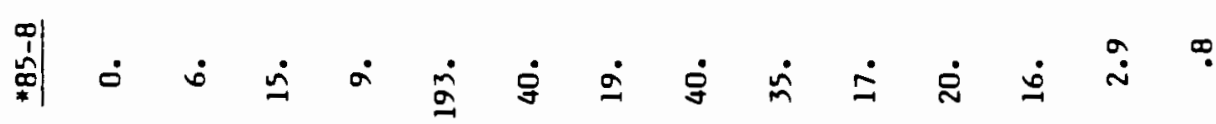

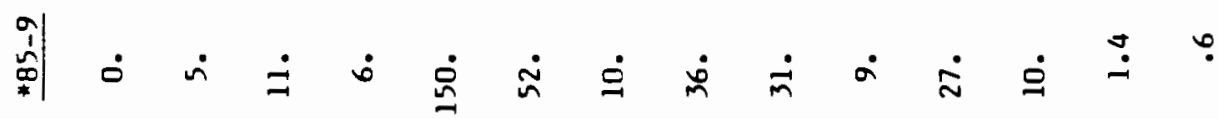

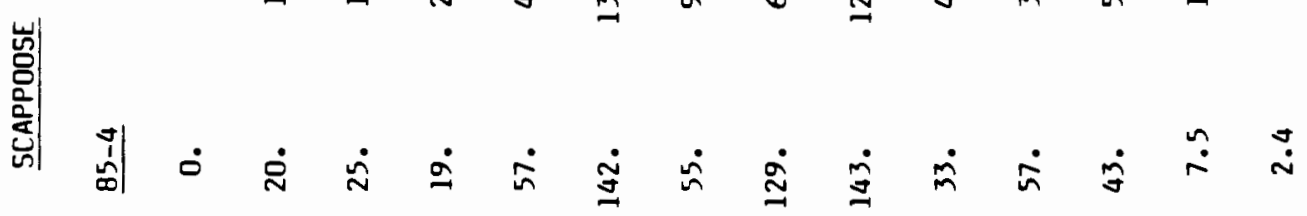

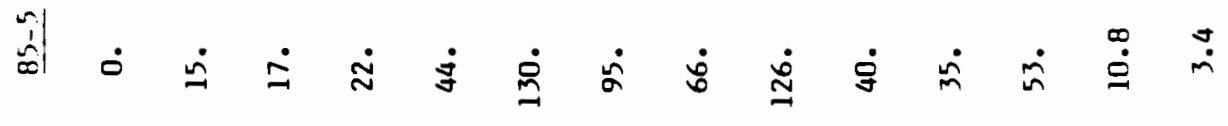

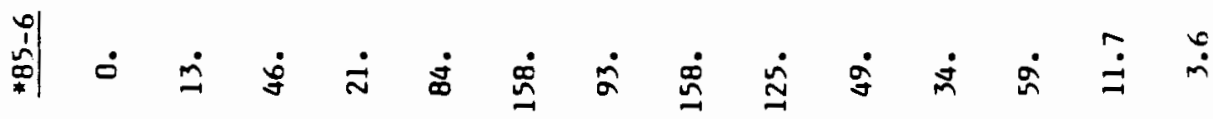

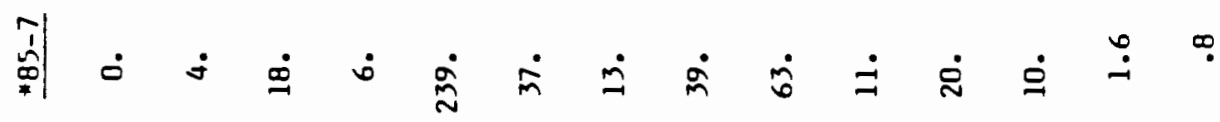

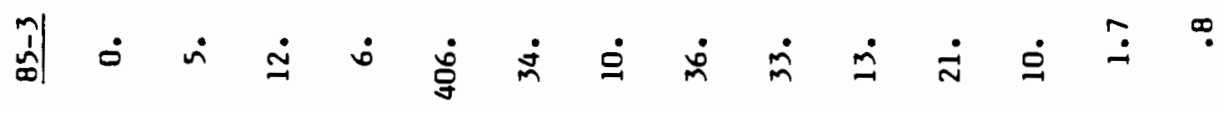

章

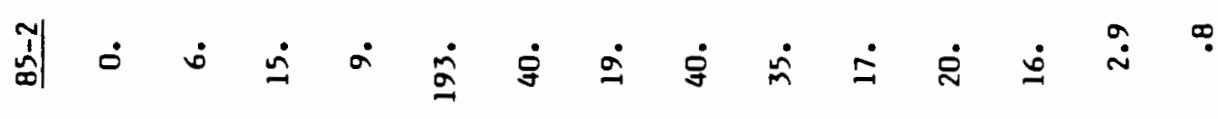

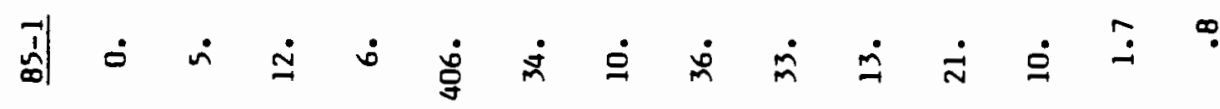

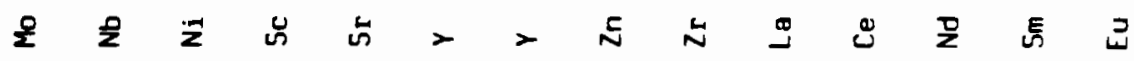




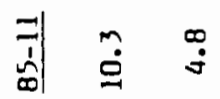

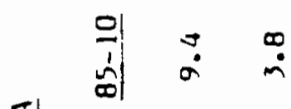

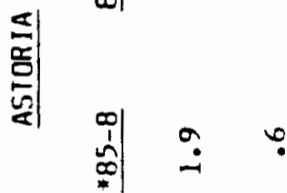

竞

nิ

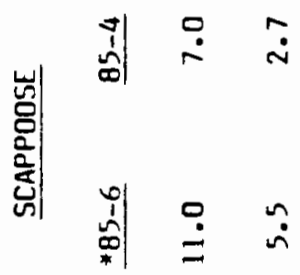

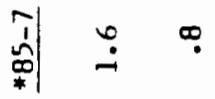

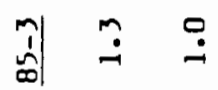

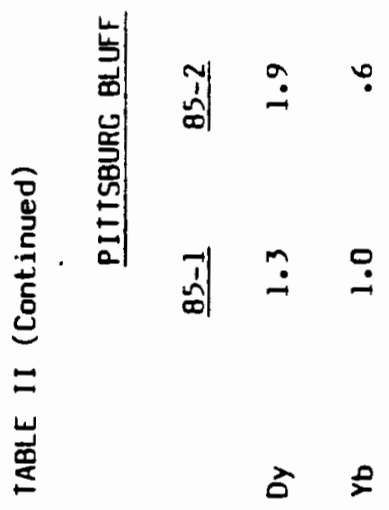




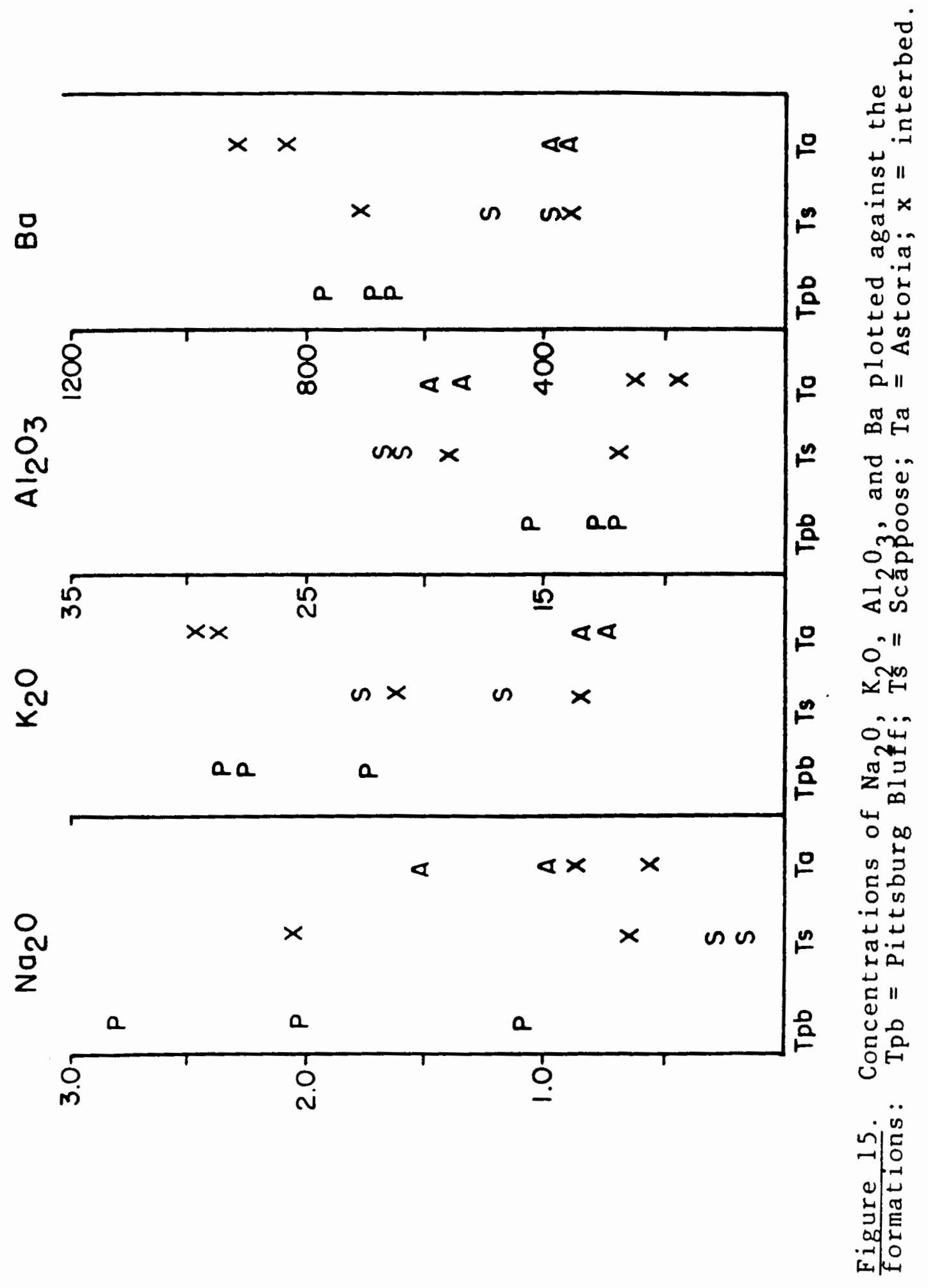




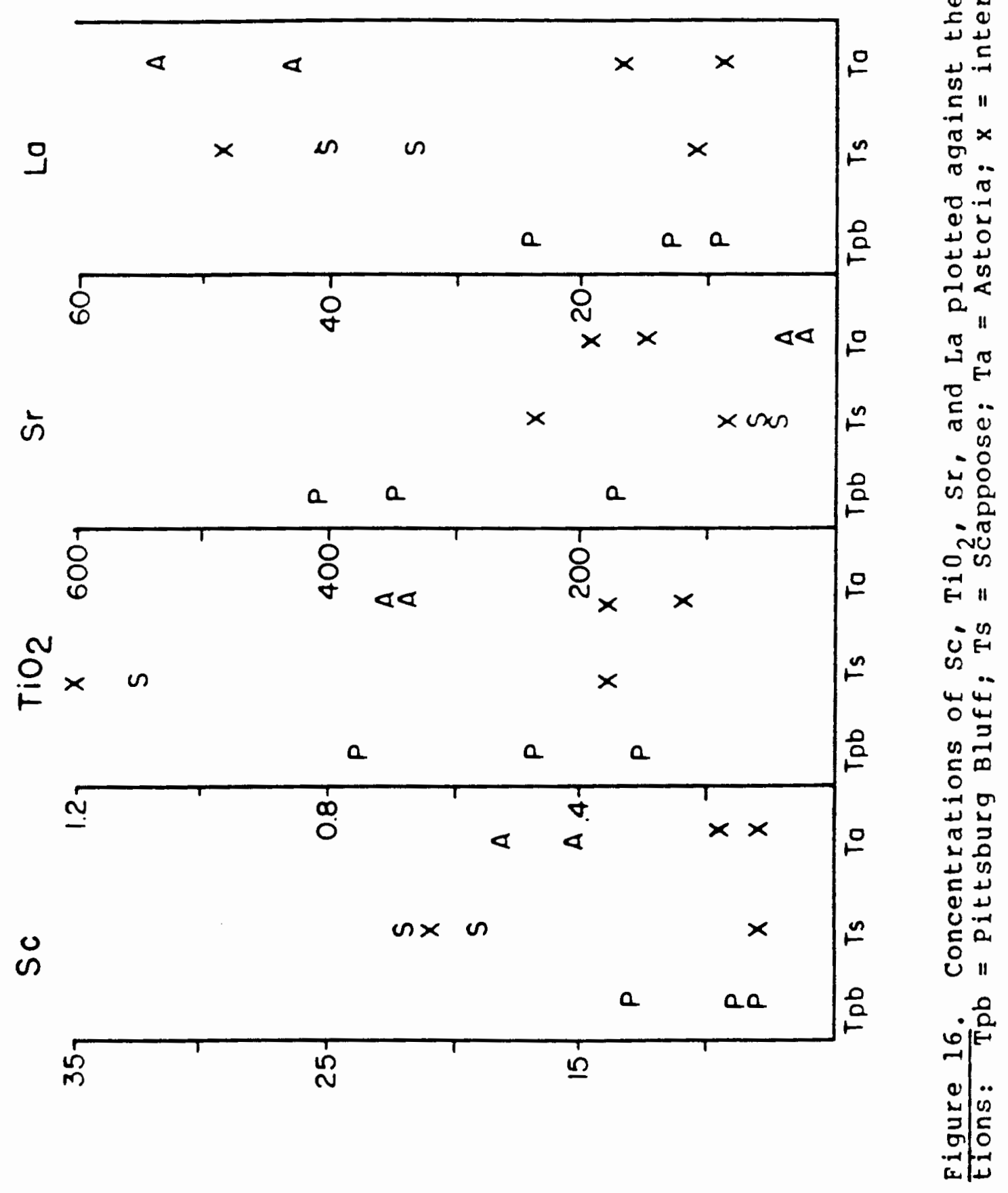




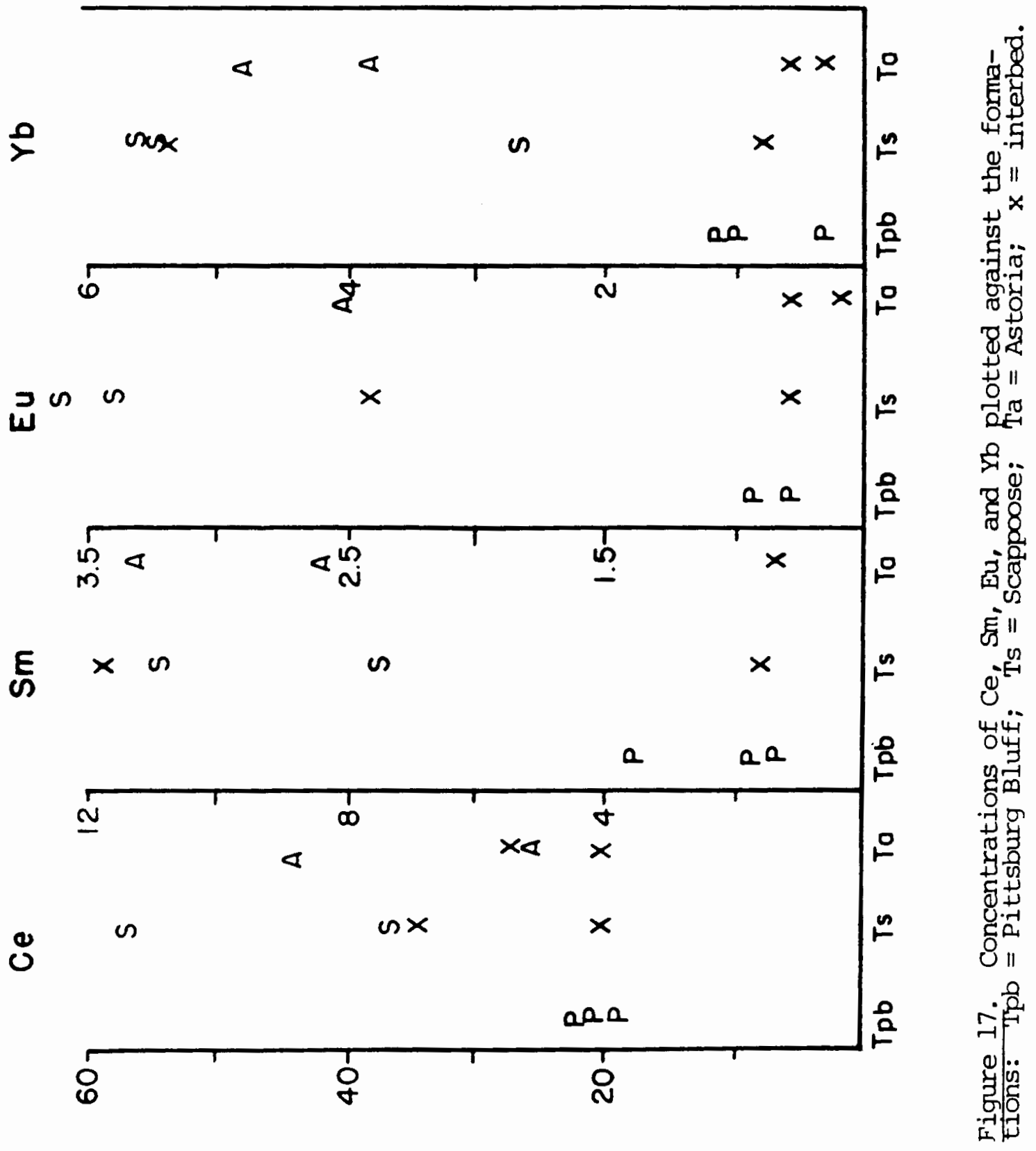


Formation. When the ratio of lanthanum and samarium is plotted against scandium, the Astoria samples plot in similar fields (Figure 18). Based on the work of Kadri and others (1983) this would indicate that the provenance for the Scappoose and Astoria Formations was the same. The higher concentrations of scandium indicates the influence of the Columbia River Basalt Group on the provenance of these formations.

The Scappoose and Astoria Formation interbed that underlies the Sand Hollow flow of the Frenchman springs Member shows minor and trace element concentrations that are similar to the Pittsburg Bluff Formation rather than the Astoria and Scappoose Formation as expected. This may indicate that the interbed was derived from a reworking of rocks from the Pittsburg Bluff Formation.

The Scappoose Formation interbed that lies between the high Mgo flow of the Grande Ronde Basalt and the Ginkgo flow of the Frenchman springs Member shows minor and trace element concentrations that are similar to the scappoose and Astoria Formations.

Major element analyses were made of ten basalt samples by Dr. Hooper (Table III), and six other analyses were given to the author by Dr. M. H. Beeson of portland state University. All of the basalt samples are from either the Grande Ronde Basalt or the Frenchman springs Member of the Columbia River Basalt Group (Figure 19). 


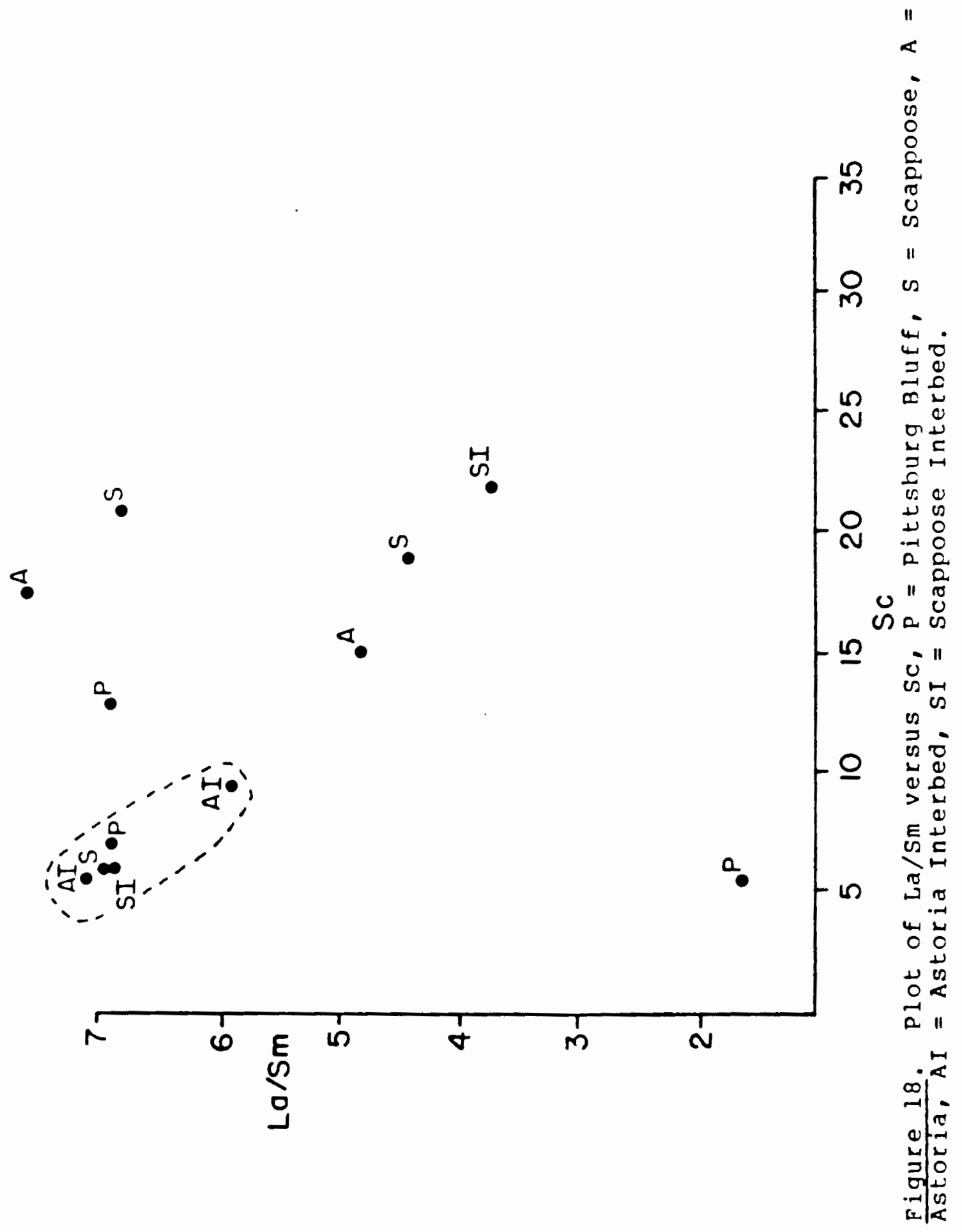



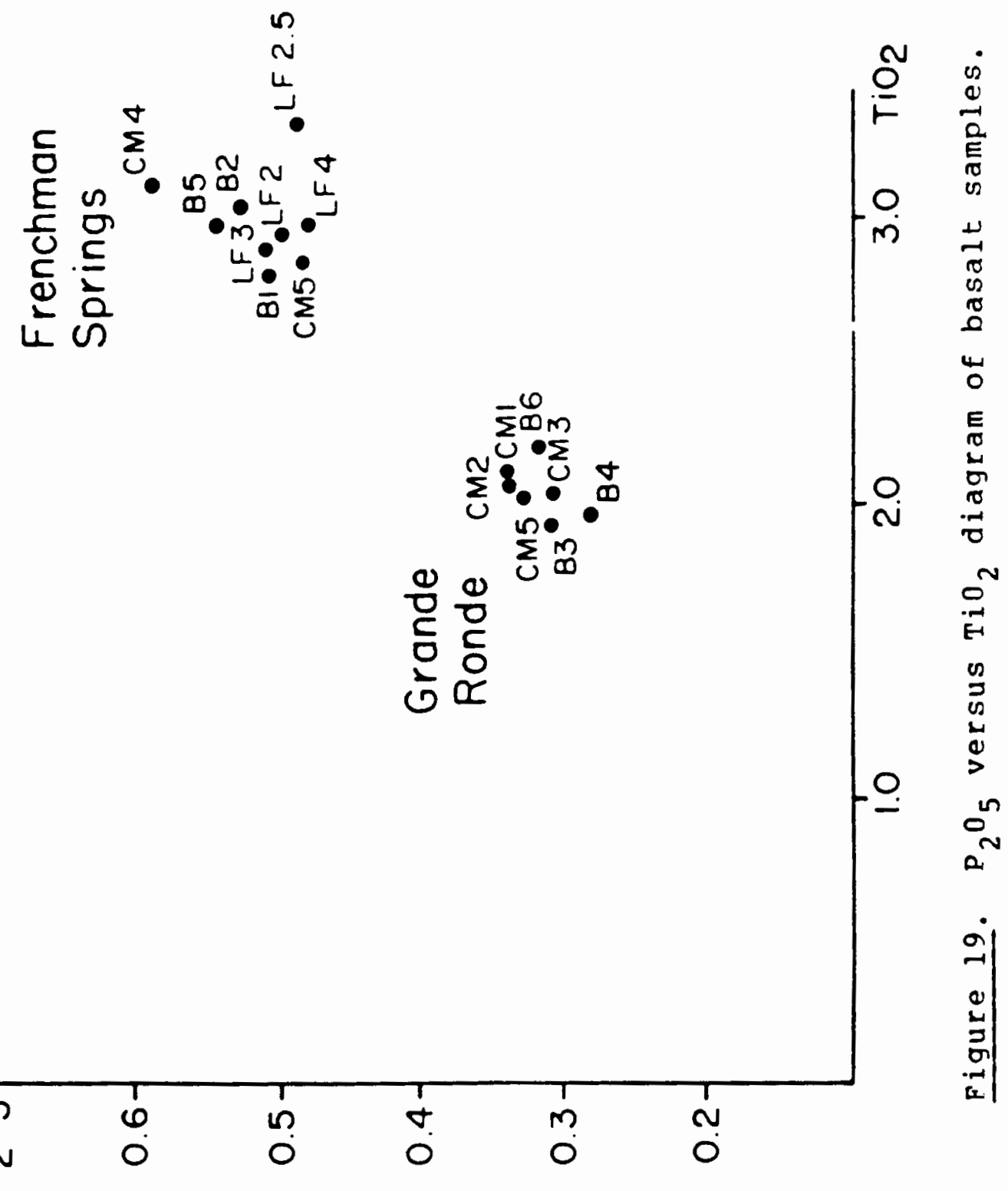


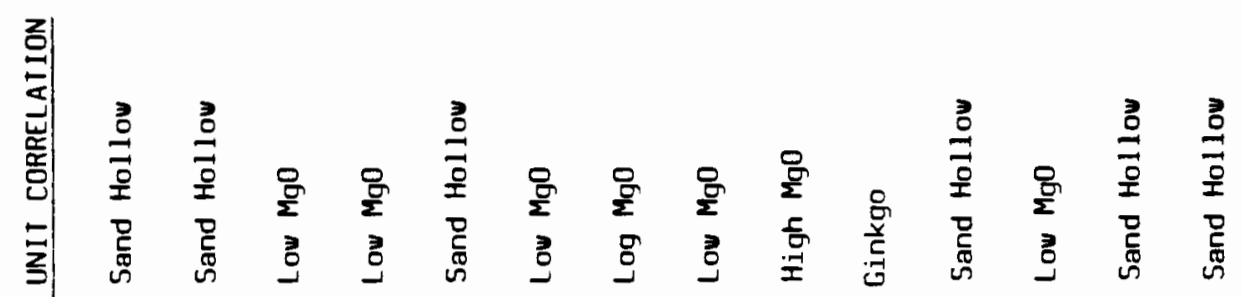

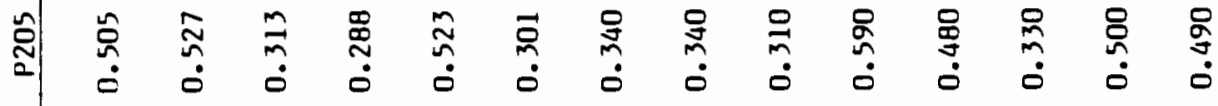

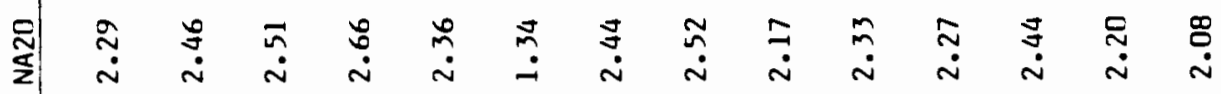

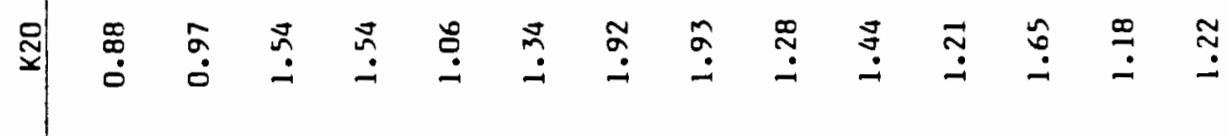

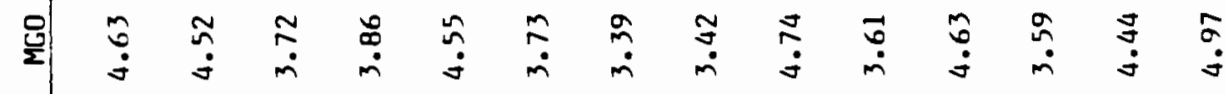

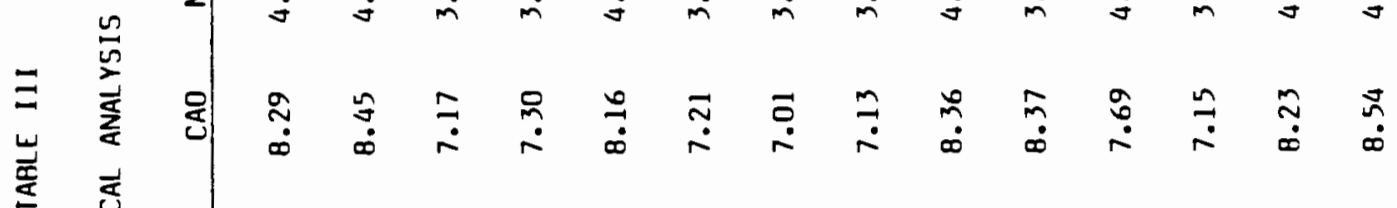

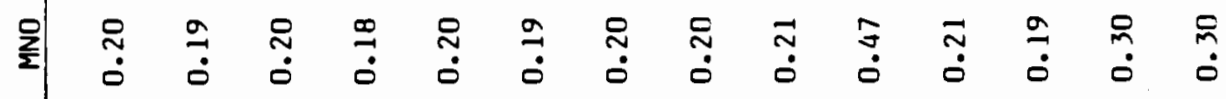

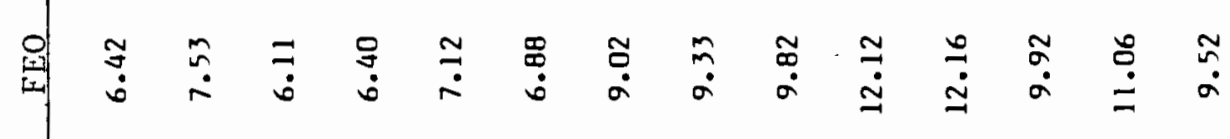

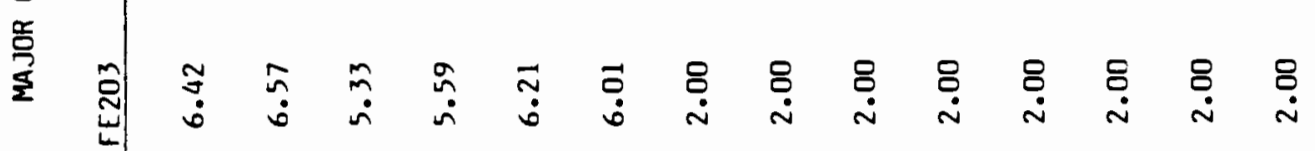

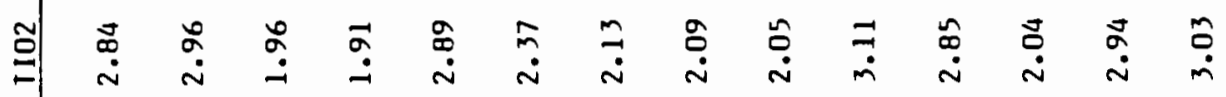

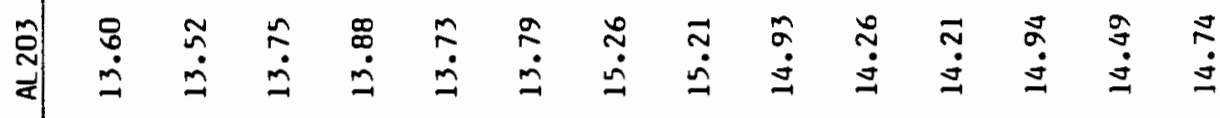

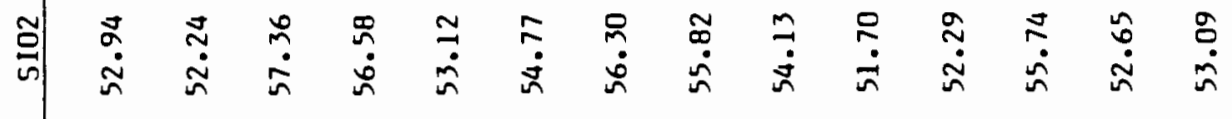

离 


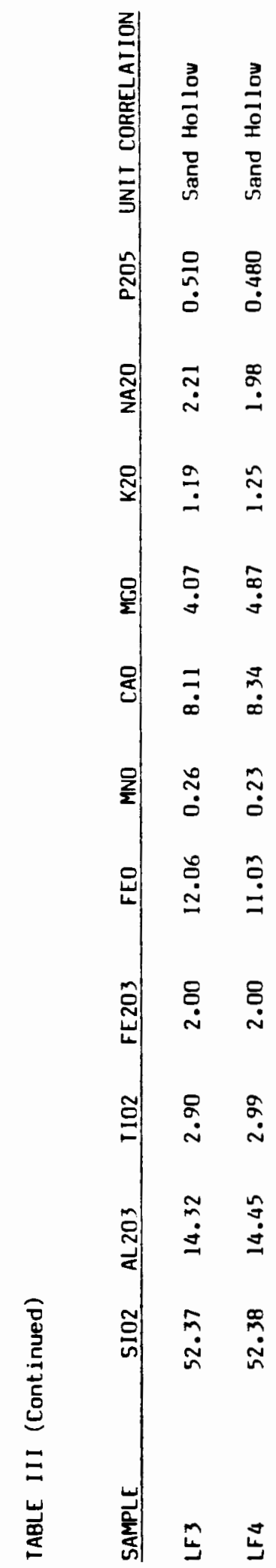


The Grande Ronde Basalt may be distinguished geochemically from the Frenchman Springs Member by a higher percentage of Si02 and a lower percentage of Ti02 and P205 (Siems, 1974). The low Mgo flows of the Grande Ronde Basalt are characterized by a lower concentration of Mgo than the high Mgo flows of the Grande Ronde Basalt. 


\section{PETROGRAPHY}

Seventeen rock samples of the Pittsburg Bluff, Scappoose, and Astoria Formations were studied in thin section. Five hundred grains were counted in ten rows of 50 points per row. In some samples, it was necessary to count more than ten rows.

The samples range from very fine grained to coarse sandstone. The sandstone samples are poorly to moderately sorted with angular to subangular grains and very little matrix. The rocks are composed predominantly of feldspar, rock fragments, quartz and mica (Appendix 1).

plagioclase is the most prevalent feldspar in both the Astoria and Scappoose Formations as well as the Pittsburg Bluff Formation. In the interbeds underlying the sand Hollow flow of the Wanapum Basalt, the percentage of potassium feldspar is nearly equal to plagioclase. The plagioclase is often twinned displaying lamellar twinning. The composition of the plagioclase ranges in composition from oligoclase to andesine (An20-50). The potassium feldspar often displays perthitic texture.

Both monocrystalline and polycrystalline quartz are present in most of the samples. The polycrystalline quartz is generally undulatory, often showing sutured grain boundaries. The scappoose formation contains very little 
polycrystalline quartz. In the samples from the interbed beneath the sand Hollow flow, the percentage of monocrystalline and polycrystalline quartz are nearly equal with sutured grain boundaries and undulatory extinction common in the polycrystalline type quartz.

Both biotite and muscovite are present; however, the mica is more prevalent in the finer grained sandstones. In the scappoose formation, some of the biotite grains are deformed.

Rock fragments make up a large percentage of the grains in all of the sandstone samples. Volcanic rock fragments are the most abundant constituent of the pittsburg Bluff Formation as well as the sandstones of the Astoria and Scappoose Formations which are marginal to the basalt flows. Andesitic and basaltic fragments are common in the interbeds as well as micrographic granitic and a few lineated metamorphic rock fragments. The microgranitic rock fragments are seen only in the coarser samples.

The composition of the sandstone is determined by its provenance (Dickinson and Suczek, 1979). The tectonic influence on the provenance is reflected in the framework grain composition of the sandstone. Dickinson and suczek (1979) delineate three major provenances when framework grains are plotted on QFL (Figure 20) and QMFLt (Figure 21) triangular diagrams: continental block; dissected magmatic arc; and magmatic arc. The sandstone from continental 


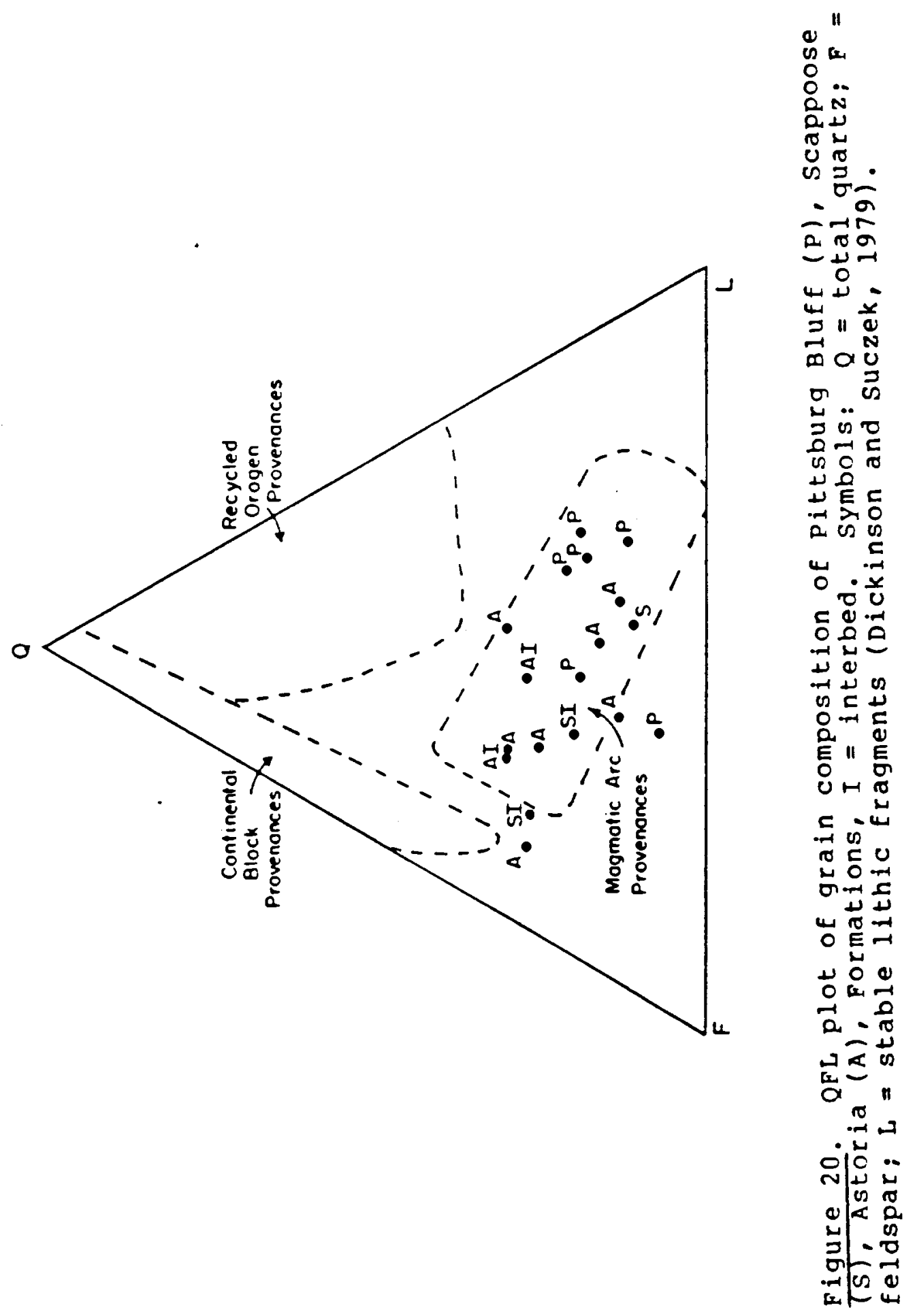




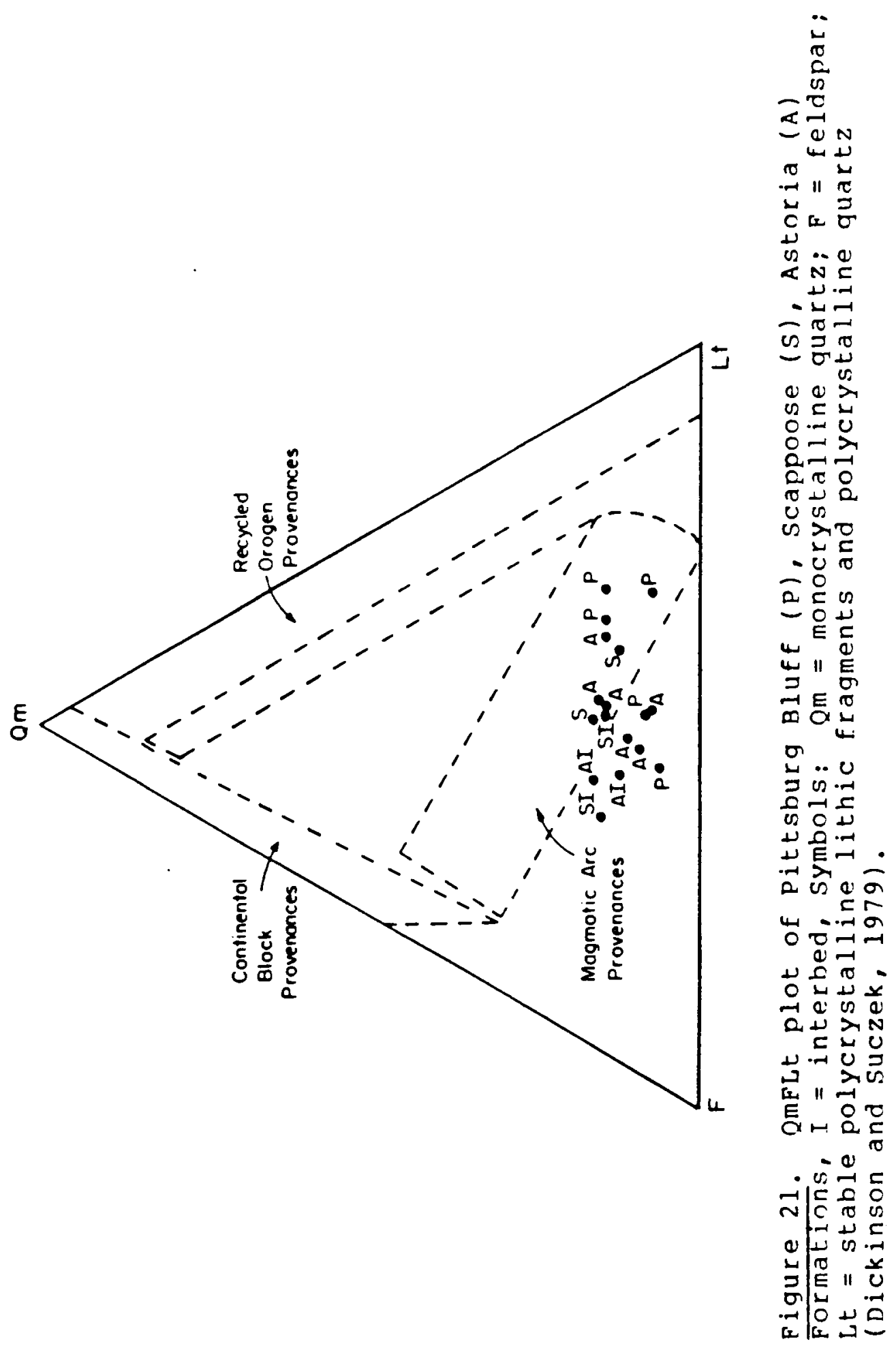


block provenances contains high percentages of quartz and feldspars with lesser percentages of stable lithic fragments. The larger abundance of quartz and feldspars indicates derivation from a plutonic source. The dissected magmatic arc sandstone contains mostly quartz and stable lithic fragments indicating the magmatic arc has been dissected contributing plutonically derived grains to the provenance. The magmatic arc is characterized by many stable polycrystalline lithic grains including polycrystalline quartz. Lesser amounts of feldspar and little quartz characterize the magmatic arc provenance which includes subduction zones and forearc basins.

When the sandstone samples from the Pittsburg Biuff, Scappoose, and Astoria Formations are plotted on the QFL and QmFLt triangular plots (Figures 20 and 21 ) they all fall into the magmatic arc provenance. Kelty (1981) hypothesized a more granitic type provenance for the scappoose Formation, but when his data are compared to the provenance types delineated by Dickinson and suczek (1979) they fall into the magmatic arc provenance.

The influence of the basalt on the sandstone petrography is probably minimal because the basalt flows tend to weather to clay rather than forming sand-sized detrital grains.

The heavy minerals comprise a very small percentage of the minerals in the sandstone samples (Appendix 2) from the 
Astoria and Scappoose Formations. The predominant heavy minerals include zircon, epidote, augite, hypersthene, and three types of hornblende: blue-green; olive-brown; oxyhornblende.

Blue-green hornblende is derived from metamorphic sources (Deer and others, 1963), hypersthene comes from intermediate volcanic rocks, and augite is derived from rocks of mafic composition. The scappoose and Astoria Formations samples both show the influence of volcanic rocks on their heavy mineral suites. The interbed underlying the Sand Hollow flow contains 108 to 158 augite while the interbed underlying the Ginkgo flow is rich in hornblende. 


\section{CORRELATION}

Kelty (1981) and Kelty and Van Atta (1985) describe basaltic conglomerate at or near the base of the scappoose Formation at oak Ranch creek, the railroad cut north of Buxton, and at Lindsay Lake. This conglomerate is generally associated with fluvial lithic arkosic sandstone. Kadri (1982) correlates the Scappoose Formation rocks on Clatskanie Mountain with the conglomerate Van Atta and Kelty (1985) find directly beneath the low Mgo basalt flows. The basal conglomerate on Clatskanie Mountain is overlain by 17 meters of fluvial quartzose lithic arkosic sandstone and silstone (Figure 8 ). This corresponds with the measured section of Kelty (1981; Figure 12) four miles to the east of Clatskanie Mountain. In both cases, the lower conglomerate is composed of clasts of mudstone and basalt, and it is overlain by fluvial lithic arkosic sandstone. On the main part of Clatskanie Mountain, the Scappoose sandstone and siltstone beds are overlain by flows of the Grande Ronde Basalt, while on the flanks of the mountain, the scappoose formation seems to be overlain by flows of the Frenchman springs Member.

The basalts flowed down river valleys and filled topographic lows. When the Grande Ronde Basalt flows filled topographic lows, they were more resistant to erosion than 
the surrounding sediments with the result that surrounding sediments were eroded. These topographic lows provided channels for the next basalt flows. In turn, the sedimentary rocks surrounding these later flows were eroded resulting in exposure of older sedimentary rocks beneath the younger flows.

The Scappoose Formation is not exposed near the columbia-clatsop county line where a correlation of the Astoria and Scappoose Formations could be made based on field relationships.

In the western part of the mapped study area, flows of the Columbia River Basalt Group overlie the deeply eroded Pittsburg Bluff formation. The scappoose formation does not appear to be present in this area. In the field, the Scappoose formation is not lithologically distinguishable from the Pittsburg Bluff Formation if the underlying conglomerate is not present. However, the scappoose Formation may be differentiated from the Pittsburg Bluff Formation by geochemistry (Kadri and others 1983; this paper). Determining which fossils are representative of the scappoose Formation would help differentiate it from the Pittsburg Bluff Formation.

The area to the west of the clatsop county line was investigated for beds stratigraphically equivalent to the Scappoose formation exposed in the vicinity of clatskanie Mountain. Arkosic sandstone beds, interbedded with and 
marginal to wanapum Basalt flows, were sampled in the vicinity of Nicolai Mountain and near Big Noise Creek.

The fluvial interbed between the Ginkgo (informal)

flow and the sand Hollow (informal) flow of the Frenchman Springs Member on Clatskanie Mountain also crops out, northwest of Nicolai Mountain, on Shingle Mill Road in section $8, T .7 N$. R. 6W. (Figure 22) and on Oklahoma Hill section 21, T. $8 \mathrm{~N}$. R. 6W. along U.S. Highway 30 . In both of these locations it lies between a flow of high Mgo Grande Ronde Basalt and a Sand Hollow flow of the Wanapum Basalt. The Ginkgo flow is not present in these two areas. On Shingle Mill Road, the interbed is approximately 20 meters thick and has a narrow shoestring geometry, and on Oklahoma Hill it has a thickness of approximately 60 meters. Stratigraphically, petrographically, and geochemically, these two beds are equivalent.

Murphy (1981) equates this interbed to the Vantage Member of the Ellensburg Formation of south central Washington. This is debatable because the Vantage Member was deposited during the hiatus in volcanism between the Grande Ronde and the Wanapum Basalts. The lowest flow of the Frenchman Springs Member in the northwestern columbia county is the Ginkgo flow, and on Clatskanie Mountain, this interbed lies above the Ginkgo flow. In each case, the interbed is overlain by the stratigraphically higher sand Hollow flow; however, on clatskanie Mountain, the interbed 


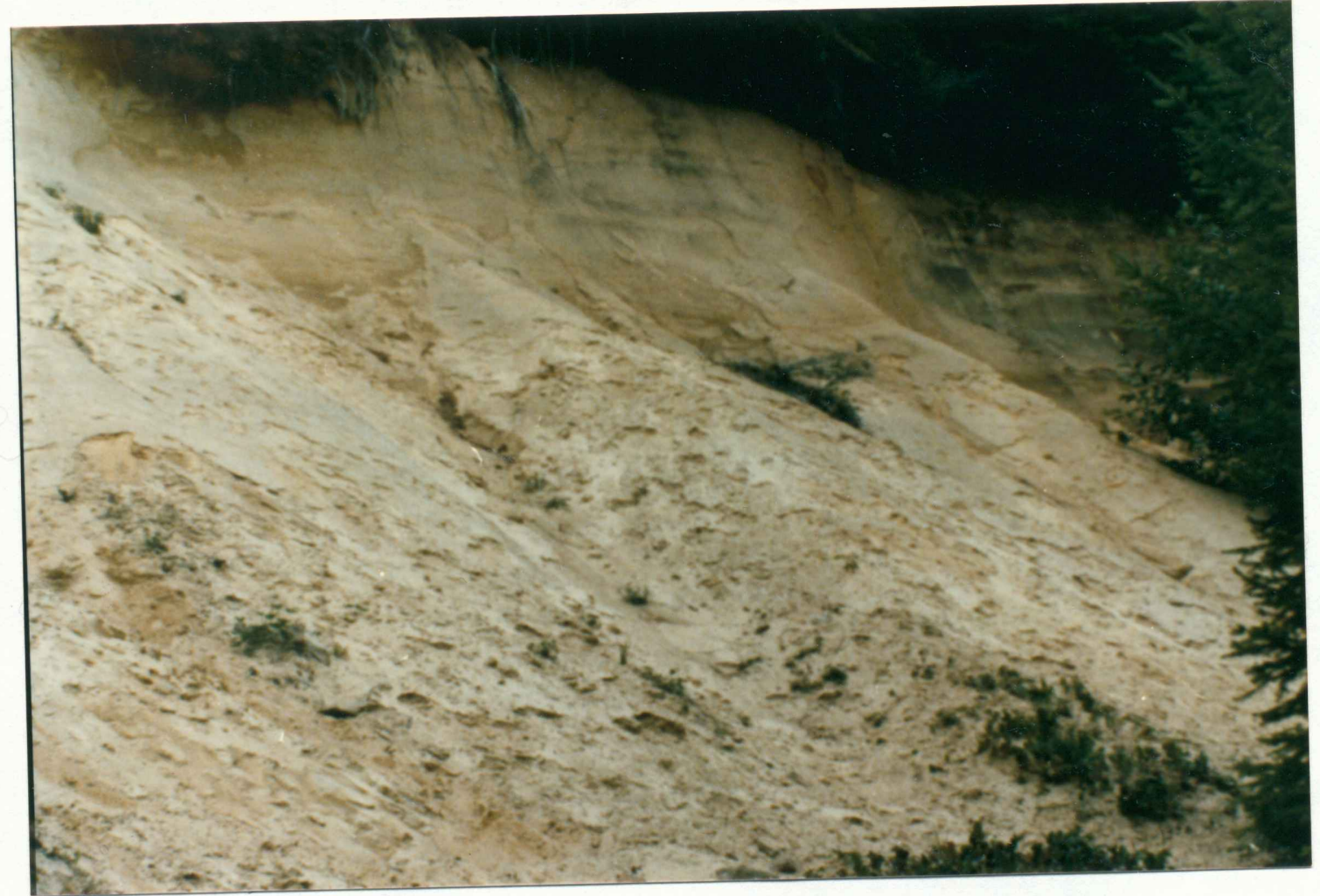

Figure 22. Fluvial sandstone interbed on shingle Mill Road. 
between the high Mgo flow and the Ginkgo flow has a different geochemistry.

The geochemistry of these three interbeds underlying the sand Hollow flows is similar to that of the Pittsburg Bluff Formation rather than the scappoose and Astoria Formations. These beds may have been derived from reworked Pittsburg Bluff Formation rocks. The Pittsburg Bluff Formation contains more volcanic rock fragments (Van Atta, 1971) than the rocks of the interbeds, but reworking may have removed many of the lithics and concentrated the quartz. The Pittsburg Bluff Formation had at least several hundred meters of relief in several areas such as Lindsay Lake and Skunk Cabbage Ridge when the Frenchman Springs Member basalts flowed into the area. The flows disrupted drainage resulting in the streams flowing along the margins of the flows, thus eroding the valley walls composed of the Pittsburg Bluff Formation.

A major drainage system was not present in northwestern columbia county during vantage time. At this time it was located a considerable distance to the south; however, a rapid change in drainage occurred when the Ginkgo flow filled the canyon. This may have resulted in spillage to the north along the present-day Columbia River (M. H. Beeson, personal communication, 1986).

The loosely consolidated, orange, massive sandstone intercalated with the basalts on clatskanie Mountain is 
geochemically, petrographically, and stratigraphically equivalent to sandstone on the AT\&T Road that connects the Nicolai Mountain Mainline with Shingle Mill Road, and with sandstone on Big Noise Creek Road (Section 25, T. 8N. R. $7 W$ ). Niem (1985) has mapped the beds on the Big Noise Creek Road as interbeds of the Frenchman springs Member of the Wanapum Basalt. The sediments on Clatskanie Mountain appear to be deposited on the margins of the basalt flows.

\section{Summary}

The basaltic conglomerate at the base of the scappoose Formation on clatskanie Mountain corresponds to the basaltic conglomerate that has been found at the base of the Scappoose Formation in areas to the southeast of the study area by Kelty (1981) and Van Atta and kelty (1985). This conglomerate contains clasts derived from the columbia River Basalt Group thus confirming the revision of the age of the Scappoose Formation by Van Atta and Kelty (1985). On Clatskanie Mountain, an interbed of the scappoose Formation which lies between the Ginkgo flow and a flow of the sand Hollow basalt is stratigraphically, petrographically, and geochemically equivalent to Astoria Formation interbeds exposed on Nicolai Mountain and U.S. Highway 30 . 


\section{DISCUSSION AND CONCLUSIONS}

\section{DEPOSITIONAL ENVIRONMENT}

The Keasey, Pittsburg Bluff, and Scappoose Formations show a general shallowing upward trend. Based on Van Atta's (1971) description of the keasey Formation, only the middle member (informal) is exposed in the study area. The mudstone of the Keasey Formation indicates deposition in a low energy environment and probably represents a deep marine environment.

The lowest unit of the Pittsburg Bluff Formation, which crops out only in section $8, T .7 \mathrm{~N} . \mathrm{R} .5 \mathrm{~W}$, is better exposed to the west in clatsop county where it is a glauconitic, well stratified, fine grained sandstone with interbedded coarse, poorly sorted sandstone. The glauconite and the relatively uniform fine grain size indicate deposition in a marine environment. Miall (1984) states that glauconite forms only in shallow marine environments. The coarse grained sandstones may have been deposited below fair weather wave base during storms (Reineck and Singh, 1980). Murphy (1981) identified some molluscan fossils from this lower sandstone adjacent to the clatsop Columbia County line. Four of the fossils he identified were Perse pittsburgensis Durham and Spicula pittsburgensis Clark and the trace fossils Scalarituba and planolites. Murphy 
(1981) describes the contact between the lower marine sandstone and the upper sandy siltsone of the Pittsburg Bluff Formation as a sharp lithologic break. This break between the upper and lower parts of the Pittsburg Bluff Formation is not exposed in northwestern Columbia county.

The upper tuffaceous sandy siltstone which overlies the marine sandstone coarsens upward indicating a shallowing upward sequence to a fluvial environment. The fluvial environment of deposition is indicated by the poor sorting, lignitic wood, pebbly lenses, and the small scale trough cross-bedding. Warren and Norbisrath (1946) interpreted the top of the pittsburg Bluff Formation, near Willark, which is located about $1 \mathrm{~km}$ southeast of Pittsburg, on the East Fork of the Nehalem River, as deltaic.

The relatively thin beds of breccias and pillows underlying the subaerial basalt flows indicate the basalt flowed into relatively shallow water. The flows appear to have overridden the breccia and were deposited subaerially forming columns and entablatures consistent with subaerial basalt flows.

The plumes of sandstone within the basalt may have been caused by loading of the basalt to a critical density and the subsequent upward flow of the wet sand analogous to load structures in sedimentary rocks. The brecciated basalt clasts and pillows enclosed in the sandstone indicates the invasive nature of the basalts. Niem (1985), from his 
investigation of well cuttings in clatsop county, reports intrusive Columbia River Basalt Group flows (less than 3 to 100 meters thick) in late Eocene sedimentary rocks at a depth of over 2000 meters.

The geometry of the basalt flows and the small scale primary structures in the sedimentary rocks of the scappoose Formation indicate a fluvial environment of deposition. The ribbon-like geometry of the basalt flows in northwestern columbia county indicate these flows filled channels and topographic lows (Figure 23). The channelfill geometry of the basalt flows combined with the poor sorting, lignitic wood, conglomerate, short cross-bedding, and planar cross-bedding in the scappoose Formation indicate a fluvial environment. This would support the hypothesis of Kadri (1982) that these rocks were deposited in an estuarine environment. 


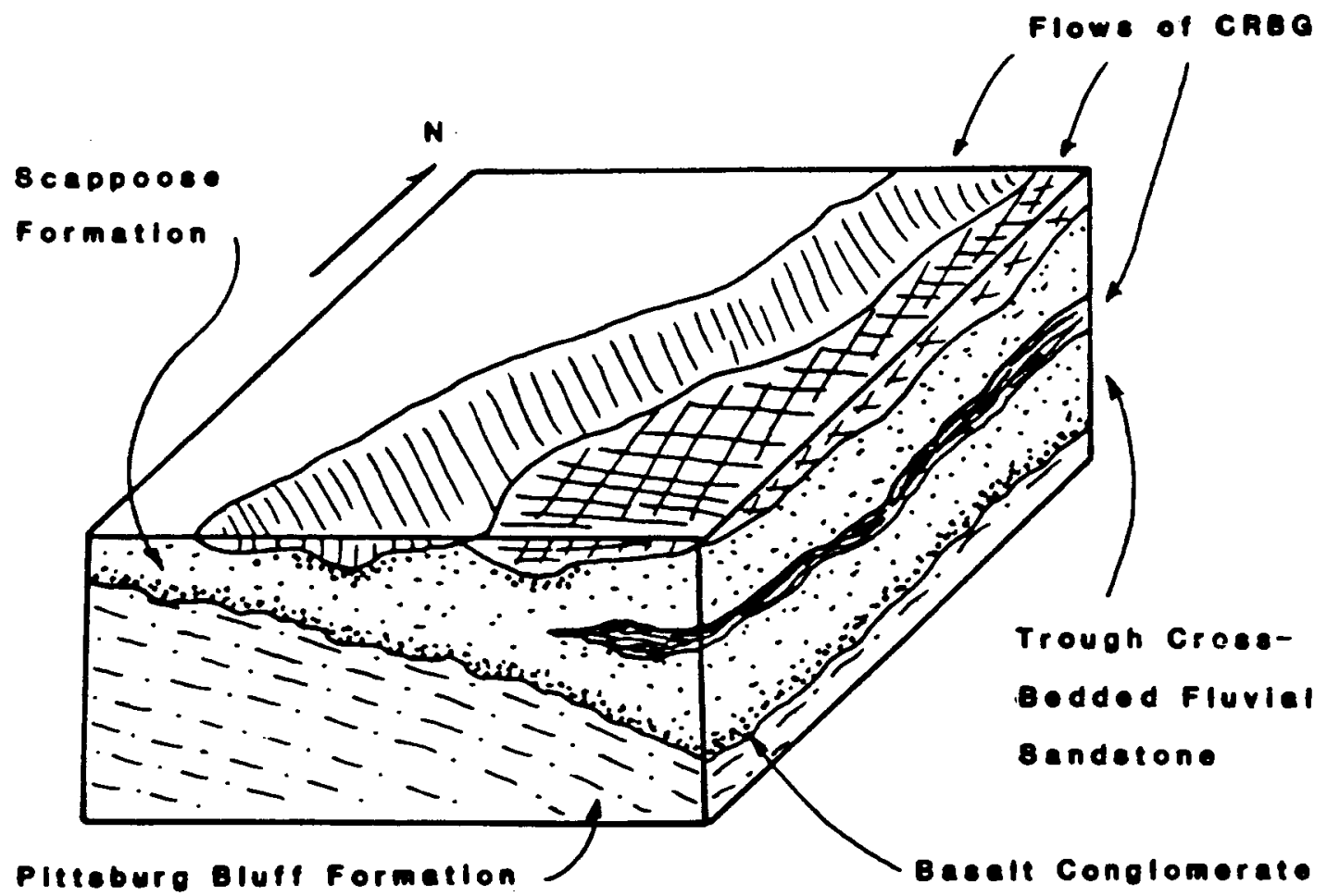

Figure 23. Sketch diagram of channel-fill geometry of the basalt flows. 
Alger, M., 1985, Geology of the Mist Gas Field: Mist Gas Field Technical Program Preprints, Northwest Petroleum Association, Beaverton, Oregon, May, 1985, 4 p.

Armentrout, J. A., Hull, D. A., Beaulieu, J. D., and Rau, W. W., 1983, Correlation of Cenozoic stratigraphic units in western Oregon and Washington: Oregon Department of Geology and Mineral Industries Oil and Gas Investigation $7,98 \mathrm{p}$.

Armentrout, J.A., and Suek, D. H., 1985, Hydrocarbon exploration in western oregon and washington: Amer. Assoc. Petroleum Geol. Bull., vol. 69, p. 672-643.

Beeson, M. H., Perttu, R., and Perttu, J., 1979, The origin of the Miocene basalts of coastal oregon and

Washington: an alternative hypothesis: oregon Geology, vol. 41, no. 10, p. 159-166.

Beeson, M. H., Frecht, K. R., Reidel, S. P., and Tolan, T. L., 1985, Regional correlations within the Frenchman springs Member of the Columbia River Basalt Group: New insights into the middle Miocene tectonics of northwestern Oregon: Oregon Geology, vol. 47, no. 8, p. 87-96.

Cooper, M. D., 1980, Sedimentation, stratigraphy, and facies variation within the early to middle Miocene Astoria Formation in Oregon: Oregon State Univ., Corvallis, unpub. doctoral dissertation.

Coryell, G. F., 1977, stratigraphy, sedimentation, and petrology of the Tertiary rocks in the Bear CreekWickiup Mountain-Big Creek area, Clatsop County, Oregon: Oregon State Univ., Corvallis, unpub. M.S. thesis, $178 \mathrm{p}$.

Deer, F. R. S., Howie, R. A., and zussman, J., 1963, Rock Forming Minerals, vol. 4, Framework Silicates: New York, John Wiley and Sons, $435 \mathrm{p}$.

Dickinson, W. R., and suczek, C. A., 1979, Plate tectonics and sandstone compositions: Amer. Assoc. Petroleum Geol. Bull., vol. 63, no. 12, p. 2164-2182.

Drake, E. T., 1982, Tectonic evolution of the oregon continental margin: Oregon Geology, vol. 44, p. 15-2l. 
Duncan, R. A., 1982, A captured chain in the Coast Range of Oregon and Washington: Journal of Geophysical Research, vol. 87, p. 10827-10837.

Heller, P. L., Peterman, Z. E., O'Neil, J. R., and Shafiquillah, M., 1985, Isotopic provenance of sandstones from the Eocene Tyee Formation, Oregon Coast Range: Geol. Soc. Amer. Bull., vol. 96, p. $770-780$.

Kadri, M. M., 1982, structure and influence of the Tillamook uplift on the stratigraphy of the Mist area, Oregon: Portland State Univ., Portland, Oregon, unpub. M.S. thesis, $87 \mathrm{p}$.

Kadri, M. M., Beeson, M. H., and Van Atta, R. O., 1983, Geochemical evidence for changing provenance of Tertiary formations in northwestern oregon: Oregon Geology, vol. 45, p. 20-22.

Kadri, M. M., Kelty, K. B., Ordway, E., Timmons, D. M., and Van Atta, R. O., 1981, preliminary geologic map of Townships $4,5,6$, and $7 \mathrm{~N}$., Ranges 4 and 5 W., N.W. oregon: unpub. geologic map.

Kelty, K. B., 1981, stratigraphy, lithofacies and environment of deposition of the Scappoose Formation in central Columbia County, oregon: Portland state Univ., Portland, Oregon, unpub. M.S. thesis, 81 p.

Mackin, J. H., 1961, A stratigraphic sectuon in the Yakima Basalt and the Ellensburg Formation in south-central Washington: Washington Div. Mines and Geology Dept., Inv. $45 \mathrm{p}$.

MCDonald, H. C., 1969, Geologic evaluation of radar imagery from Darien Province, Panama: Modern Geology, vol. 1, no. 1, p. 1-63.

Mckee, E. H., Swanson, D. A., and Wright, T. L., 1977, Duration and volume of Columbia River Basalt volcanism, Washington, Oregon and Idaho: Geol. Soc. Amer. Abstract with Programs, vol. 9, no. 4, p. $463-464$.

Miall, A. D., 1984, Principles of sedimentary Basin Analysis: New York, Springer-Verlag, $490 \mathrm{p}$.

Murphy, T. M., 1981, Geology of the Nicolai Mountain-Gnat Creek area, Clatsop County, northwestern oregon: Oregon State University, Corvallis, unpub. M.S. thesis, $355 \mathrm{p}$. 
Newton, V. C, Jr., and Van Atta, R. O., 1976, Prospects for natural gas production and underground storage of pipeline gas in the upper Nehalem River basin, Columbia County-Clatsop Counties, Oregon: Oregon Department of Investigation $5,56 \mathrm{p}$.

Niem, A. R., and Niem, W. A., 1985, Oil and Gas Investigation of the Astoria Basin, Clatsop and northernmost Tillamook Counties: Northwest oregon: Department of Geology and Mineral Industries Oil and Gas Investigation $14,8 \mathrm{p}$.

Reineck, H. E., and Singh, I. B., 1980, Depositional Sedimentary Environment: New York, Springer-Verlag, $549 \mathrm{p}$.

Schenck, H. G., 1927, Marine Oligocene of Oregon: Univ. of Calif., Dept. of Geol. Sciences Bull., vol. 18, no. 12 , p. $449-460$.

Siems, G. A., Bush, J. M., and Crosby, J. W., III, 1974, Ti02 and geophysical logging criteria for the Yakima Basalt correlation, Columbia Plateau: Geol. Soc. Amer. Bull., vol. 85, p. 1061-1068.

Simpson, R. W., and Cox, A., 1977, Paleomagnetic evidence for tectonic rotation of the oregon coast Range: Geology, vol. 5, p. 585-589.

Snavely, P. D., Jr., Macleod, N. S., and wagner, H. C., 1973, Miocene tholeiitic basalts of coastal oregon and washington and their relations to coeval basalts of the Columbia Plateau: Geol. Soc. Amer. Bull. vol. 84, p. 387-427.

Swanson, D. A., Wright, T. L., Hooper, P. R., and Bentley, R. P., 1979, Revisions in stratigraphic nomenclature of the Columbia River Basalt Group: U.S. Geological Survey Bulletin 1457-G, 59 p.

Van Atta, R. O., 1971, sedimentary petrology of some Tertiary formations, upper Nehalem River basin, Oregon: Oregon State University, Corvallis, unpub. doctoral dissertation, 245 p.

Van Atta, R. O., and Kelty, K. B., 1985, Scappoose Formation, Columbia County, oregon: New evidence of Age and Relation to Columbia River Basalt Group: Amer. Assoc. Petroleum Geol. Bull, vol. 60, p. 688-698. 
Warren, W., and Norbisrath, H., 1946, Stratigraphy of the upper Nehalem River basin, northwestern Oregon: Amer. Assoc. Petroleum Geol. Bull., vol. 30, p. 213-237.

Warren, W., Norbisrath, H., and Grivetti, R. M., 1945, Geology of northwestern oregon west of the willamette Valley and north of latitude 45 15': U.S. Geological Survey Oil and Gas Inv., Preliminary Map No. 42.

Waters, A. C., 1961, stratigraphic and Iithologic variations in the Columbia River basalt: Am. Jour. Sci., vol. 259, p. 583-611.

Wells, R. E., 1984, Paleomagnetic constraints on the interpretation of early Cenozoic Pacific northwest paleogeography in Nilsen, T. H., Geology of the Upper Cretaceous Hornbrook Formation, oregon and California: Pacific section S.E.P.M., vol. 42, p. 231-237. 


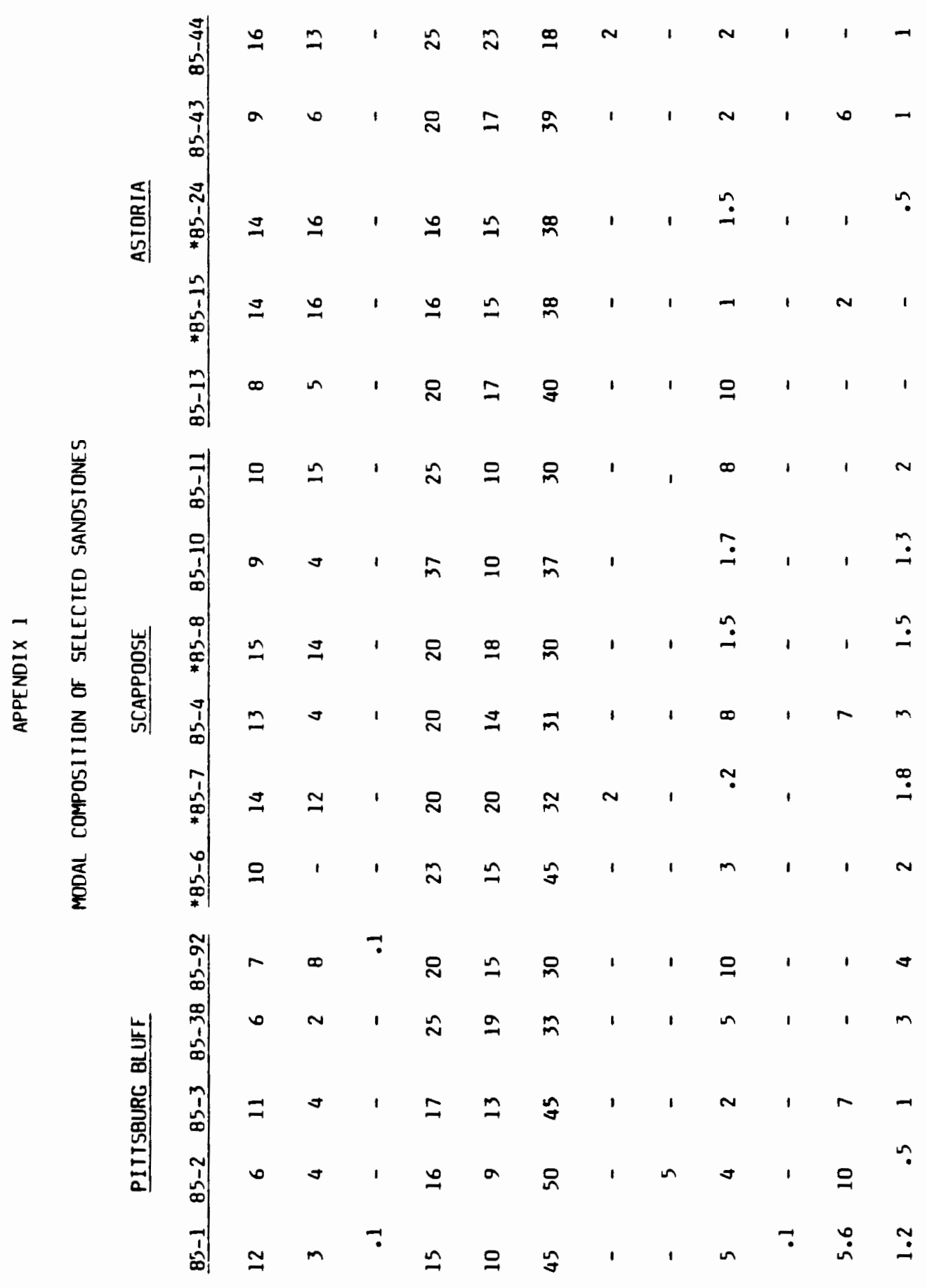

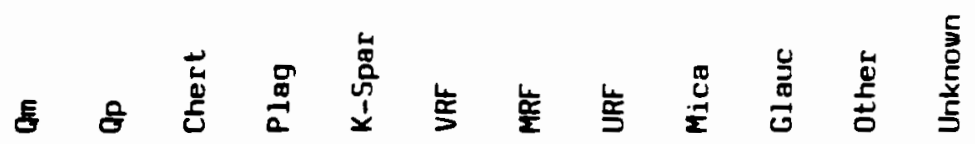




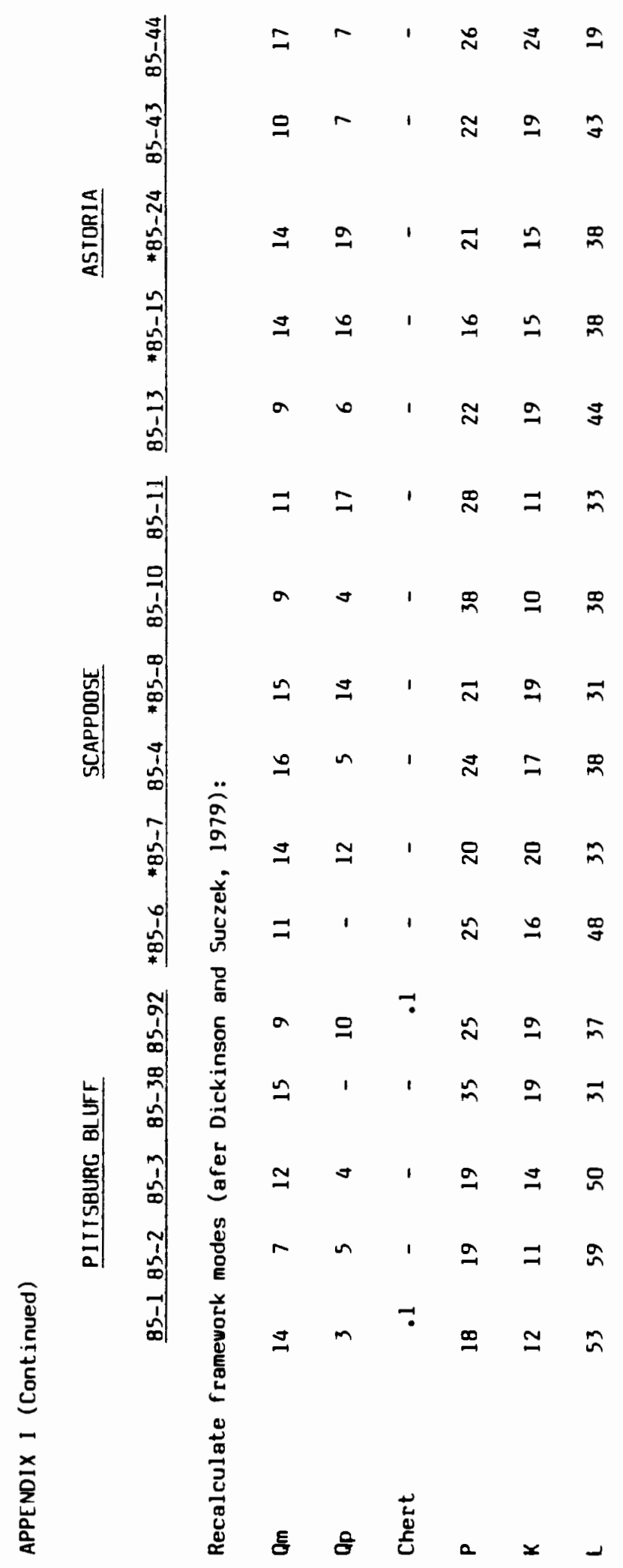




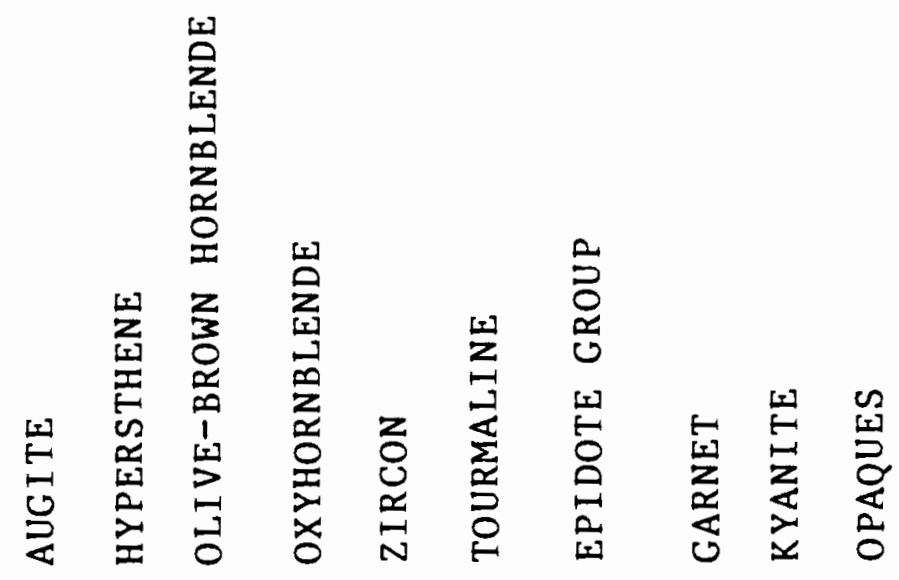

SAMPLE

\begin{tabular}{|c|c|c|c|c|c|c|c|c|c|c|}
\hline $85-92$ & 15 & 5 & 35 & & 5 & $\operatorname{Tr}$ & 5 & & 35 & Pittsburg \\
\hline$\because 85-6$ & 6 & 2 & 44 & 1 & 5 & & 10 & & 32 & Scappoose \\
\hline$\div 85-7$ & 10 & 5 & 14 & 1 & 10 & & 4 & 1 & 45 & Scappoose \\
\hline$\div 85-24$ & 12 & 6 & 18 & 2 & 8 & & 12 & 2 & 40 & Astoria \\
\hline $85-10$ & 15 & 3 & 10 & & 11 & 1 & 14 & $<1$ & 46 & Astoria \\
\hline
\end{tabular}

$*=$ interbed 
SAMPLE LOCATIONS

\section{Columbia River Basalt Group}

Bl NEl/4, NWI/4, NWI/4, Sec, 16, T. 7N, R. 6W.

B2 NEl/4, NEl/4, NWl/4, Sec. $21, T .8 \mathrm{~N}, \mathrm{R}, 6 \mathrm{~W}$.

B3 NWI/4, NEl/4, NWI/4, Sec. 3, T. 7N., R. 7W.

B4 SWI/4, SWl/4, NEl/4, Sec. 14, T. 8N, R. 7W.

B5 SWl 5 , NWI/4, SWl/4, Sec. $28, T, 7 N ., R .5 W$.

B6 NEl/4, NEl/4, SEl/4, Sec. $25, T, 7 N$, R. $5 \mathrm{~W}$.

CMI NWI/4, NWI/4, SWl/4, Sec. $27, \mathrm{~T} .7 \mathrm{~N}, \mathrm{R} .5 \mathrm{~W}$.

CM2 NWI/4, NWI/4, SWl/4, Sec. $27, T .7 \mathrm{~N}, \mathrm{R} .5 \mathrm{~W}$.

CM 3 NWl $/ 4$, NWl $/ 4$, SWl $/ 4, \sec , 27, T, 7 N$, R. 5W.

CM4 NWI/4, NWI/4, SWl/4, Sec. $27, \mathrm{~T}, 7 \mathrm{~N}, \mathrm{R}, 5 \mathrm{~W}$.

CM5 NWI/4, NWI/4, SWl/4, Sec. 27, T. 7N., R. 5W.

CMFH NEl/4, SWl/4, NWI/4, SeC. 33, T. 7N., R. 5W.

LF2 SEl/4, NEl/4, NWI/4, Sec.3, T. 6N, , R. 5W.

LF2.5 SEl/4, NEl/4, NWI/4, Sec. 3, T. 6N, , R. 5W.

LF3 NWI/4, NWI/4, NEI/4, Sec. 3, T. 6N, , R. 5W.

LF4 NWI/4, NWI/4, NEl/4, Sec. 3, T. 6N., R. 5W. 
APPENDIX III (continued)

Scappoose Formation

85-7 NWI/4, NWI/4, SWl/4, Sec. $27, T .7 \mathrm{~N}$, , R. 5W. sandstone interbed between Ginkgo and Sand Hollow 85-6 NEl/4, SWl $/ 4, \mathrm{SWl} / 4, \sec , 28, \mathrm{~T}, 7 \mathrm{~N}, \mathrm{R}, 5 \mathrm{~W}$. sandstone interbed between high Mgo and Ginkgo 85-4 SEl/4, SWl/4, NEl/4, Sec. 3, T. 6N., R. 5W. sandstone

85-5 NWl/4, NWI/4, NEl/4, Sec. 3, T. 6N., R. 5W. sandstone

85-13 SWl $4, \mathrm{swl} / 4, \mathrm{swl} / 4, \sec .2, \mathrm{~T}, 6 \mathrm{~N}, \mathrm{R}, 5 \mathrm{~W}$. sandstone

85-96 SWl/4, SWl/4, SWl/4, Sec. 2, T. 6N., R. 5W. sand stone

\section{Pittsburg Bluff Formation}

85-1 SEl/4, SEl/4, NWl/4, Sec. 11, T. 6N., R. 5W. siltstone

85-2 SEl/4, SEl/4, NWl/4, Sec. 11, T. 6N., R. 5W. silty sandstone

85-3 NEl/4, NEl/4, SEl/4, Sec. 34, T. 7N., R. 5W. siltstone

85-38 NEl/4, NEl/4, SEl/4, Sec. 34, T. 7N., R. 5W. silty sandstone

85-92 SEl/4, SEl/4, NWl/4, Sec. 11, T. 6N., R. 5W. silty sandstone 


\section{APPENDIX III (continued)}

\section{Astoria Formation}

85-10 NEl/4, NWI/4, NWl/4, Sec. 16, T. 7N, , R. 6W. sandstone

85-8 SEl/4, NWI/4, NWI/4, Sec. 8, T. 7N., R. 6W. sandstone interbed between high MgO and sand Hollow

85-11 SEl/4, NWl/4, SEl/4, Sec. 25, T. 8N., R. 7W. sandstone

85-9 SWl/4, SWl/4, NEl/4, Sec. $21, T .8 N,, R .6 \mathrm{~W}$. sandstone interbed between high $\mathrm{MgO}$ and sand Hollow

85-44 SWl/4, NWl/4, SWl/4, sec. 3, T. 7N., R. 6W. sandstone

85-43 SWl/4, NWl/4, NWl/4, Sec. $24, T .7 N ., R .8 W$. sandstone

85-24 NEl/4, NWl/4, NWl/4, Sec. 16, T. 7N., R. 6W. sandstone interbed between high MgO and sand Hollow

85-13 SEl/4, NWI/4, SEl/4, Sec. 25, T. 8N., R. 7W. sandstone

85-12 SWl/4, NWl/4, NWl/4, Sec. 24, T. 8N., R. 7W. sandstone

85-15 SEl/4, NWl/4, NWl/4, Sec. 8, T. 7N. R. 6W. sandstone interbed between high MgO and sand Hollow 